\title{
A Social History of 19th-century Farm Workers and their Families, at Jack's Houses, Kirkliston, Midlothian
}

Stuart Mitchell,* Fay Oliver** and Tim Neighbour*

With contributions by S Anderson, M Cressey, G Haggarty \& R Murdoch

* CFA Archaeology Ltd, Old Engine House, Eskmills Park, Musselburgh, East Lothian, EH21 7PQ

** Freelance Historian

Scottish Archaeological Internet Report 33, 2009 www.sair.org.uk 
Published by the Society of Antiquaries of Scotland, www.socantscot.org.uk with Historic Scotland, www.historic-scotland.gov.uk and the Council for British Archaeology, www.britarch.ac.uk

Editor Helen Bleck

Produced by Archetype Information Technology Ltd, www.archetype-it.com ISBN: 9780903903646

ISSN: $1773-3803$

Requests for permission to reproduce material from a $S A I R$ report should be sent to the Director of the Society of Antiquaries of Scotland, as well as to the author, illustrator, photographer or other copyright holder.

Copyright in any of the Scottish Archaeological Internet Reports series rests with the SAIR Consortium and the individual authors.

The maps are reproduced from Ordnance Survey material with the permission of Ordnance Survey on behalf of The Controller of Her Majesty's Stationery Office. (C) Crown copyright 2001. Any unauthorised reproduction infringes Crown copyright and may lead to prosecution or civil proceedings. Historic Scotland Licence No. GD 03032G, 2002.

The consent does not extend to copying for general distribution, advertising or promotional purposes, the creation of new collective works or resale. 


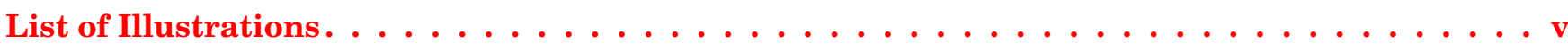

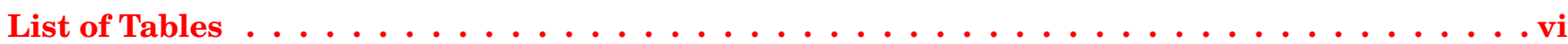

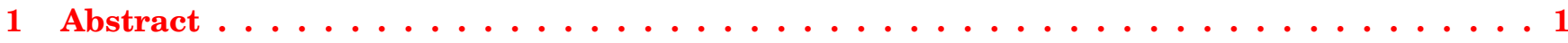

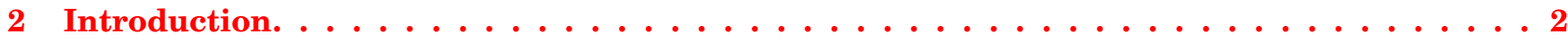

3 Background $\ldots \ldots \ldots \ldots \ldots \ldots \ldots \ldots \ldots \ldots \ldots \ldots \ldots \ldots \ldots \ldots \ldots \ldots \ldots \ldots \ldots$

4 Research Design and Layout of Report . . . . . . . . . . . . . . . 6

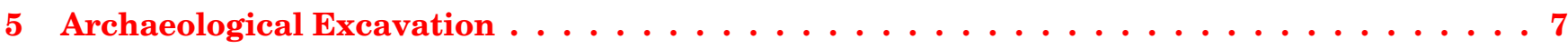

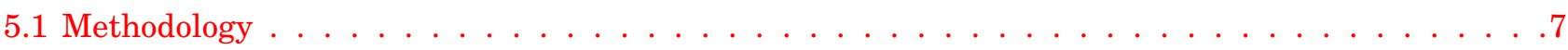

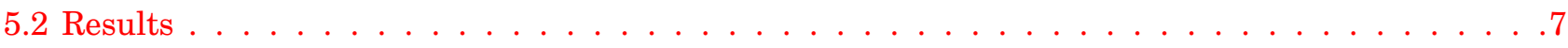

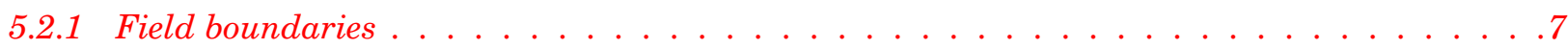

5.2 .2 Field drainage . . . . . . . . . . . . . . . . . . . . . . . . . . . . 10

5.2 .3 Draw well. . . . . . . . . . . . . . . . . . . . . . . . . 10

5.2 .4 Other features. . . . . . . . . . . . . . . . . . . . . . . . 10

5.2 .5 The midden. . . . . . . . . . . . . . . . . . . . . . . 10

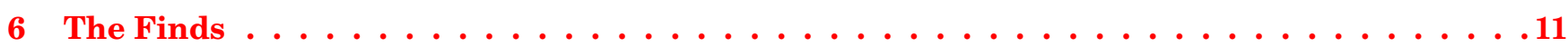

6.1 Pottery from the midden, George Haggarty . . . . . . . . . . . . . . . . . . . . . . . . 11

6.2 Glass from the midden, Robin Murdoch . . . . . . . . . . . . . . . . . . . . . 11

6.3 Organic finds from the well, Mike Cressey . . . . . . . . . . . . . . . . . . . . . 12

7 Documentary Evidence . . . . . . . . . . . . . . . . . . . . . . . . . . . . . .

7.1 Jack's houses and their inhabitants over the century $c 1830-1930 \ldots \ldots \ldots$. . . . . . . . . . 14

7.2 A history of Kirkliston parish, focusing on the 1830 s and ' 40 s. . . . . . . . . . . . . . . 16

7.3 Conclusion . . . . . . . . . . . . . . . . . . . . . . . . 21

7.4 Summary of the findings from the census and other records, Sue Anderson . . . . . . . . . . . 22

8 Discussion \& Conclusions, Stuart Mitchell \& Sue Anderson . . . . . . . . . . . . . . . . . . . . . . 23

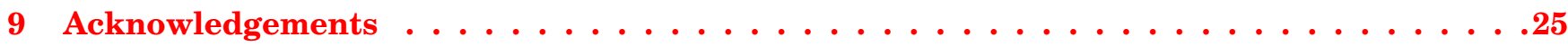

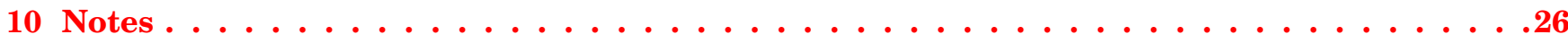

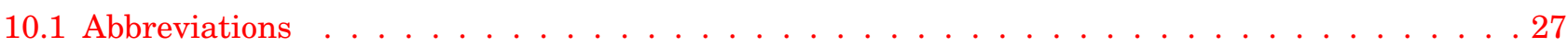




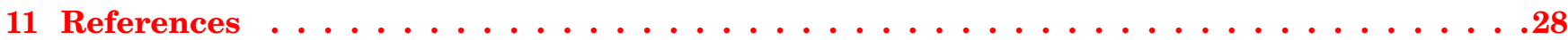

11.1 Unpublished sources . . . . . . . . . . . . . . . . . . . . . . . 28

11.1.1 National map library of Scotland . . . . . . . . . . . . . . . . . . . . . . . 28

11.1.2 General register office, Scotland . . . . . . . . . . . . . . . . . . . . . 28

11.1.3 National register of archives Scotland . . . . . . . . . . . . . . . . . . . . . 28

11.1.4 National archives of Scotland . . . . . . . . . . . . . . . . . . . . 28

11.1.5 Parliamentary papers . . . . . . . . . . . . . . . . . . . . . . 29

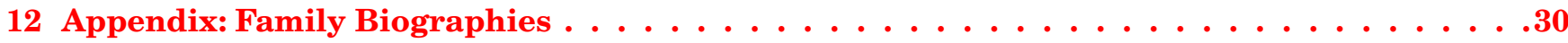

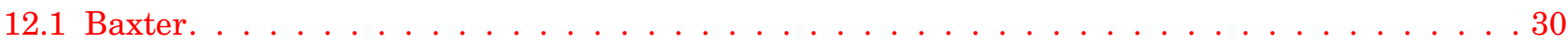

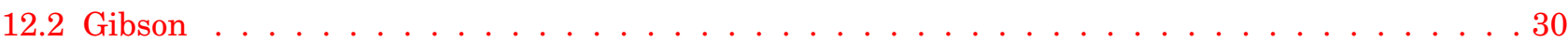

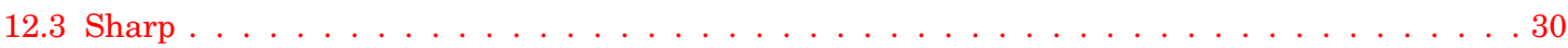

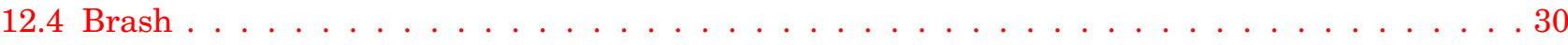

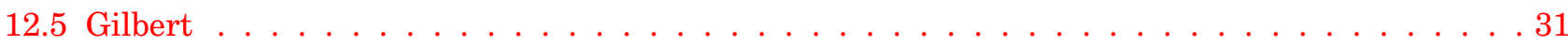

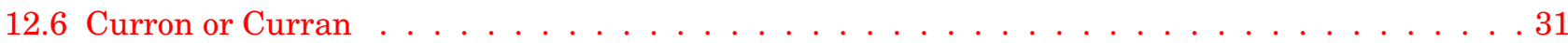

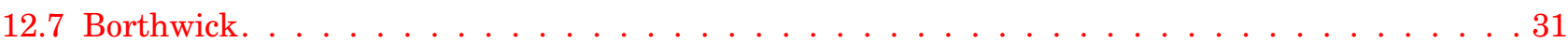

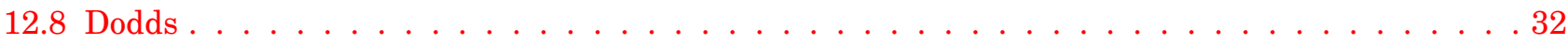

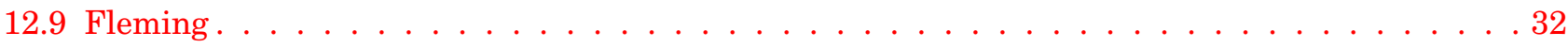

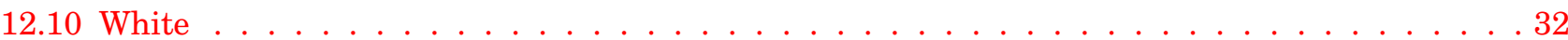

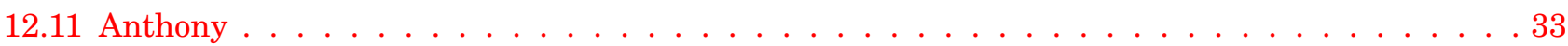

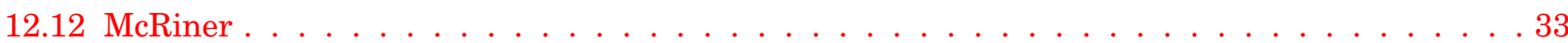




\section{LIST OF ILLUSTRATIONS}

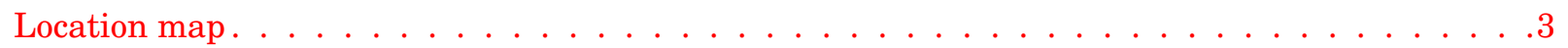

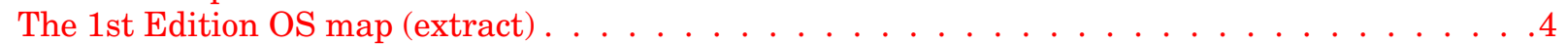

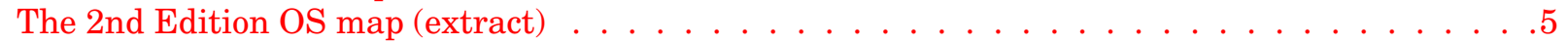

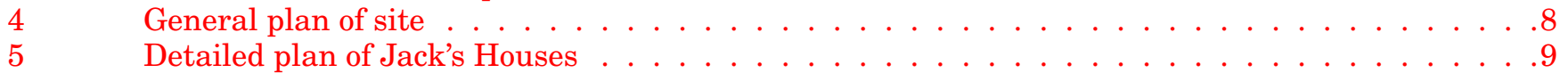




\section{LIST OF TABLES}

1

Summary of occupants based on the census and other records $\ldots \ldots \ldots$. . . . . . . . 22 


\section{ABSTRACT}

The remains of two 19th-century row cottages and associated structures and deposits were discovered at Jack's Houses, near Kirkliston. Nearby agricultural remains included a field system with boundary walls, drains and a draw well. A large rubbish dump containing pottery and ceramics has been interpreted as urban waste imported to the site to be added to the land in order to break up the clay soil for cultivation. A historical study undertaken in combination with the archaeological work afforded a view into the lives of the transient agricultural labourers and their families who occupied the houses over a century. The combined disciplines have provided us with a rare insight into a part of rural social history from the early-mid 19th to the early 20 th centuries. 


\section{INTRODUCTION}

An excavation of terraced cottages of 19th-century origin at Jack's Houses, Kirkliston (NT 1235 7540; illus 1) was carried out by CFA Archaeology Ltd during October 2003. The excavation was the third phase of archaeological study and comprised mitigation work required by John Lawson of the City of Edinburgh Council Archaeology Service (CECAS) following an initial desk-based assessment and walk-over survey conducted by Kirkdale Archaeology prior to and during October 2001, and an evaluation (Mitchell \& Suddaby 2003) which identified upstanding remains of Jack's Houses and associated deposits. The work was carried out in advance of the proposed construction of the M9 Spur extension and associated A90 upgrading works on the eastern outskirts of Edinburgh. The route of the new road passed directly over the area occupied by Jack's Houses, thus any potential archaeological information contained within this part of the road corridor was at significant risk. The project provided a rare opportunity to link detailed social historical research directly with archaeological evidence for an aspect of the 19th century that has often been ignored archaeologically in the past. 


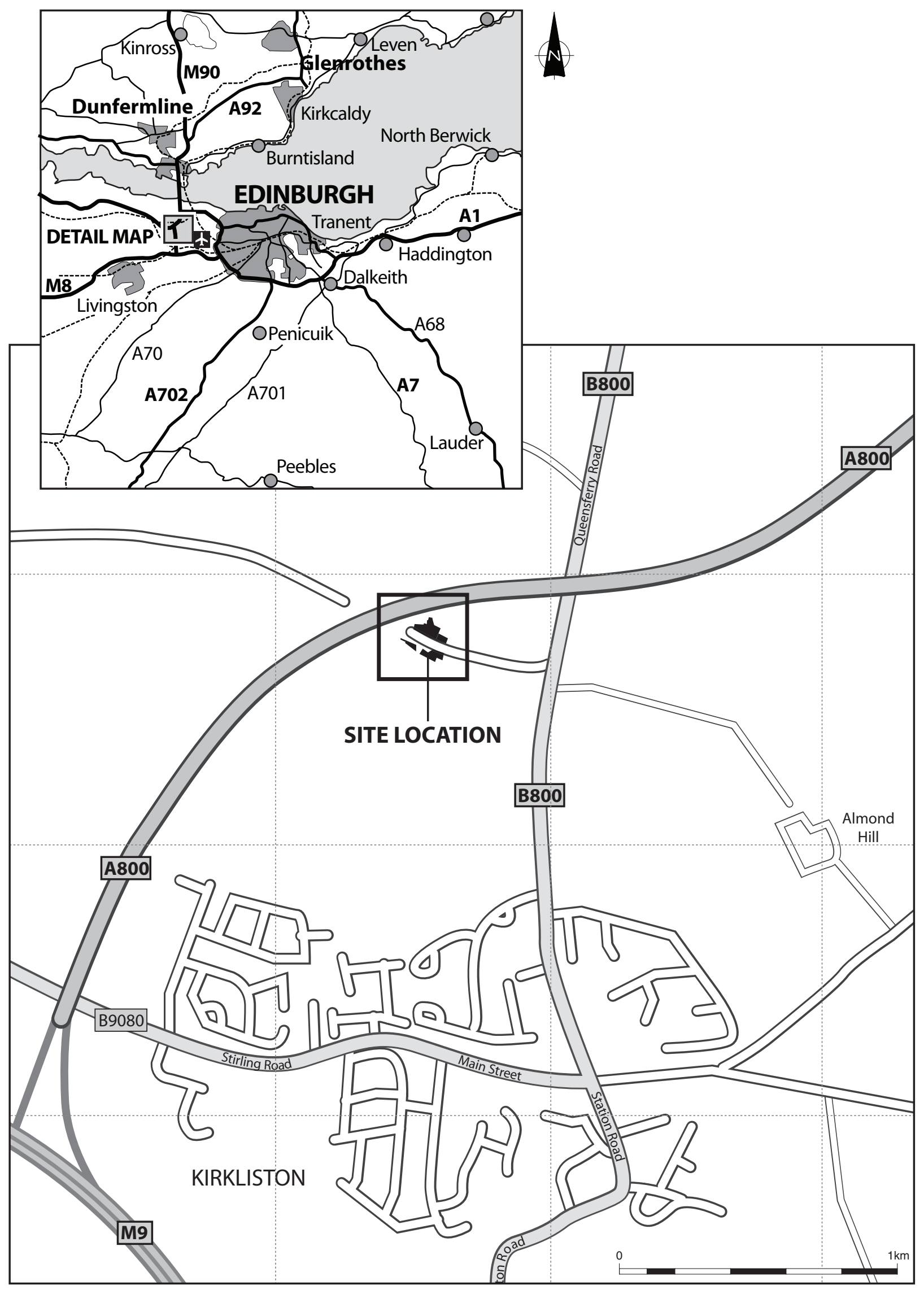

Illus 1 Location map 


\section{BACKGROUND}

The remains of Jack's Houses were situated in a field of rough pasture in the angle formed by the B800 and the existing M9 Spur road, and lay alongside an old tarmac road which formerly linked Humbie Farm with Almondhill Farm, now separated by the M9 Spur. The drift geology of the area is a mixture of firm or compact clays and silts, with occasional stones, mostly rounded volcanic boulders. Topsoil was $c 0.3 \mathrm{~m}$ deep, overlying a subsoil $0.1 \mathrm{~m}$ thick, with natural stiff grey clay at the base. The area of the site was relatively level and lay at $c 68 \mathrm{~m}$ above OD. Due to the clay subsoil, the area is very poorly drained and prone to waterlogging and flooding. An extensive field drainage system comprising both rubble drains and clay cylinder drains was present - necessary for this type of land to be agriculturally useful.

Jack's Houses were part of the Humbie Farm complex, which lay in the parish of Kirkliston. The cottages are recorded on the 1st and 2nd edition Ordnance Survey coverage (1855 and 1897 respectively) and appear in the 1841 census; estate records suggest that they were erected in the $1830 \mathrm{~s}$, although they do not appear on the 1832 edition of John Thomson's Atlas of Scotland, which depicts Humbie Farm and the track which runs past Jack's
Houses. At that time the landowner was the Earl of Hopetoun/Marquis of Linlithgow, and the farm was tenanted by George and Robert Dudgeon, descendants of whom held the tenancy throughout the 19th and 20th centuries; the Dudgeon family continue to farm at the time of writing (see below, 'Documentary Evidence').

The earliest known inhabitants, listed in the 1841 census, were, in one cottage, John Baxter, blacksmith, his wife Agnes and their seven children, and in the other, George Sharp, wright, his wife Ellen and their four children. One dwelling is described in the 1841 census as having one windowed room and the other as possessing two windowed rooms. Both buildings were listed in the 1901 census as being empty and 'out of repair', but repairs must have been carried out as the Valuation Roll records occupants shortly thereafter. Therefore, apart from occasional vacancies, the cottages were more or less continuously inhabited until being condemned in the 1930s, the last recorded occupant being Dennis Wood, a labourer. They are all depicted as upstanding buildings on the 1928 'popular' edition of the Ordnance Survey map.

The 1st and 2nd edition Ordnance Survey coverage (illus 2 and 3) shows Jack's Houses as a narrow,

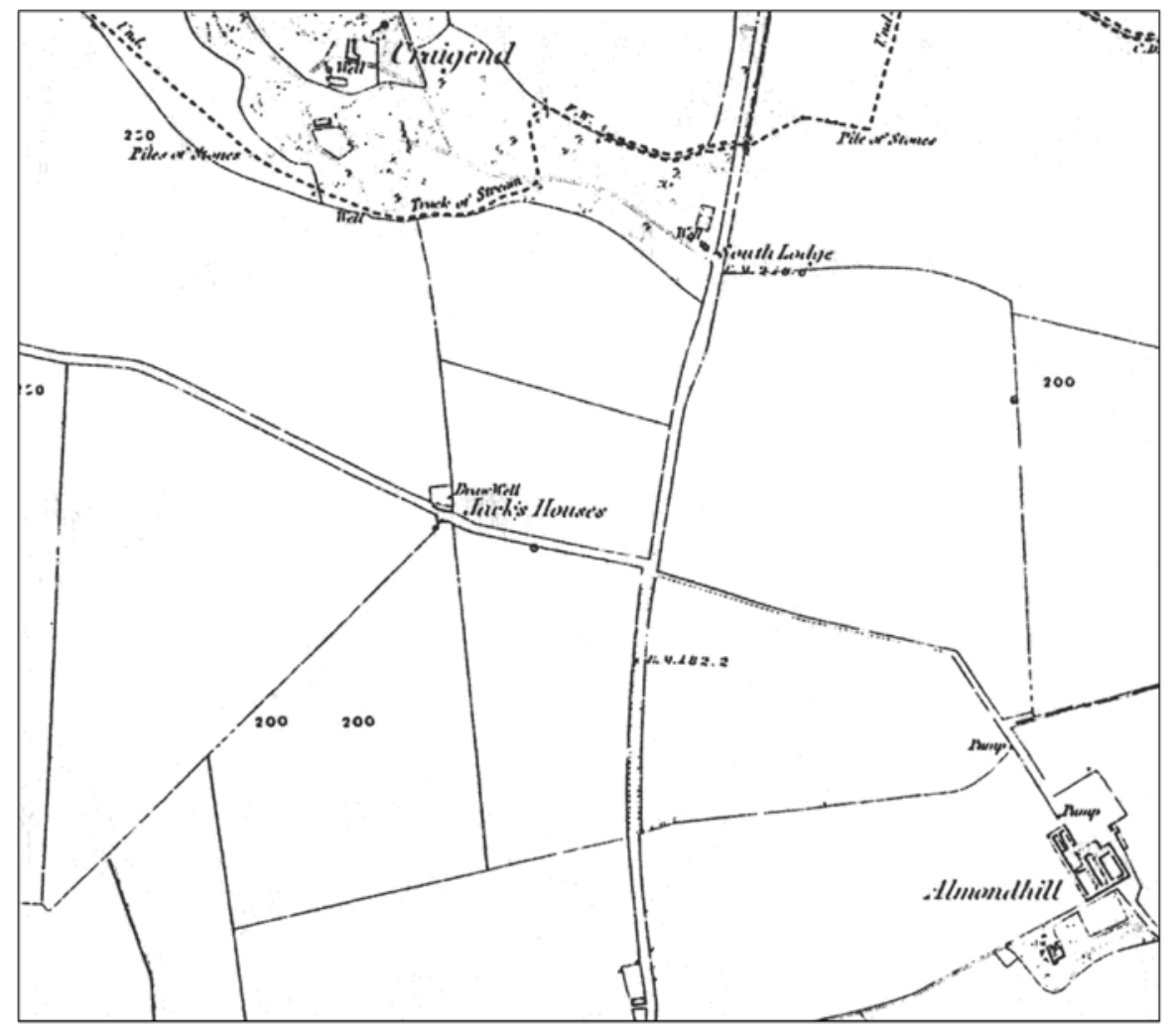

Illus 2 The 1st Edition OS map (extract) 
slightly curving row of cottages almost on the road verge, with a small enclosed area to their north. A draw well is shown within the enclosed area on the 1st edition map (illus 2).

An archaeological evaluation conducted in December 2002 (Mitchell \& Suddaby 2003) confirmed that the footings of the cottages survived in association with ditches and drystone dykes, which formed two phases of field boundaries. A large dump of 19th-century potsherds was discovered close to the cottages and traces of rig and furrow cultivation survived in the surrounding fields. The recovery of a sherd of unglazed medieval pottery from one of the furrows may indicate that the area had been cultivated in the medieval era.

While Jack's Houses were small, modest buildings, their history is not insignificant. The story of these labourers' dwellings and their occupants has much to contribute to the social history of rural life in lowland Scotland.

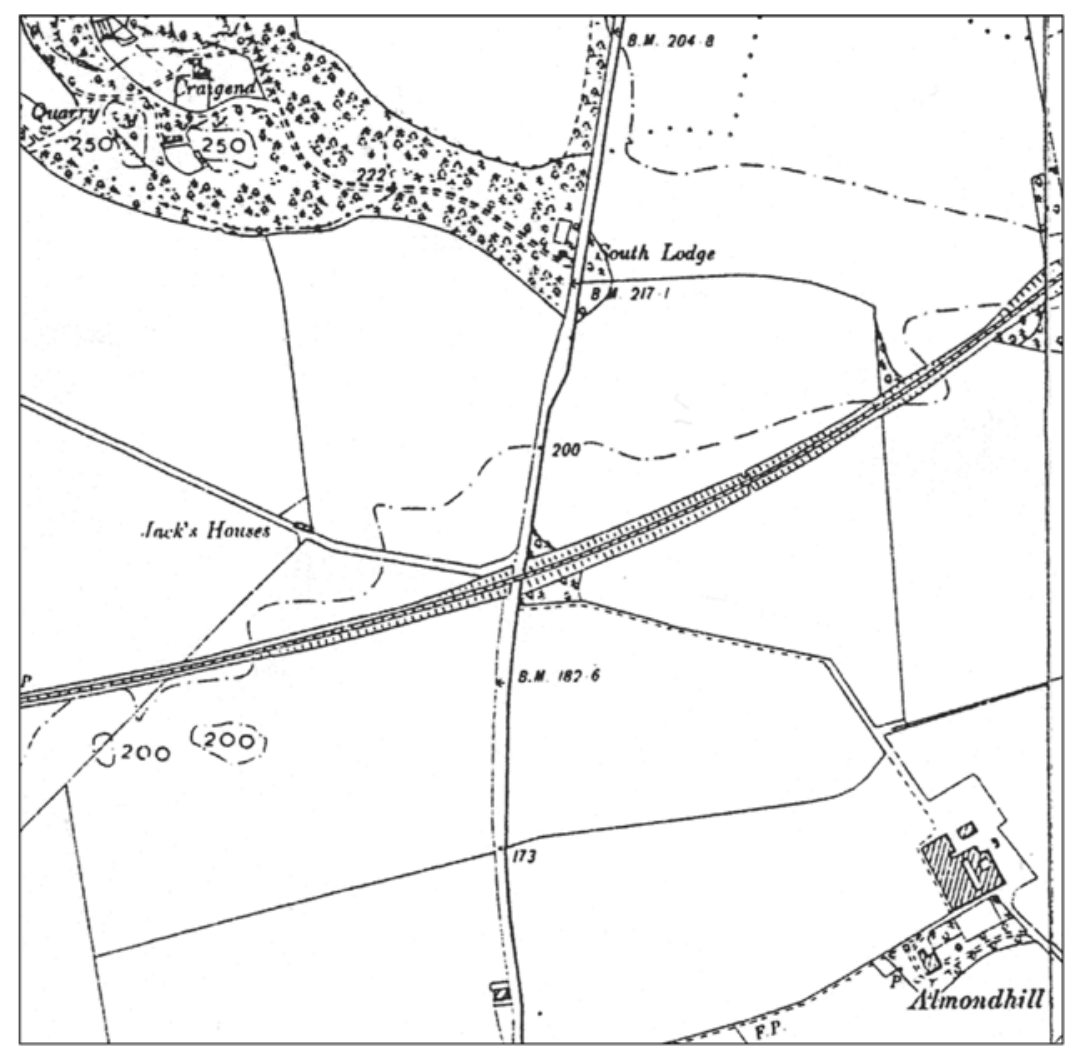

Illus 3 The 2nd Edition OS map (extract) 


\section{RESEARCH DESIGN AND LAYOUT OF REPORT}

Following the evaluation, a programme of excavation and historical research was conducted with four specific goals:

1. To test the hypothesis that settlement at Jack's Houses pre-dated the 19th century;

2. To produce a phased account of the evolution of the settlement at Jack's Houses;

3. To test the hypothesis that the large dump of potsherds discovered during the evaluation was associated with Jack's Houses;

4. To provide a social history of the settlement at Jack's Houses.
The report that follows is in three main parts. Firstly an account of the archaeological evidence is presented. This is followed by an examination of Jack's Houses and their inhabitants over the century c 1830-1930. Lastly, a broad historical account of the Parish of Kirkliston is presented, with a particular emphasis on the 1830s and 1840s, when the cottages were built and first inhabited. An appendix gives biographical details on the occupants of the cottages in the census years 1841-91. 


\section{ARCHAEOLOGICAL EXCAVATION}

\subsection{Methodology}

The requirement for the excavation was based on the findings of a walkover survey and desk-based assessment carried out by Kirkdale Archaeology, and an evaluation carried out by CFA on behalf of The City of Edinburgh Council in advance of construction of the M9 Spur extension. The evaluation demonstrated that while much of Jack's Houses had been disturbed by the insertion of a modern water pipe, significant remains survive, including extramural deposits and the large pottery dump.

A trench was positioned so as to expose completely the footings of the cottages and enclosure at Jack's Houses, as demonstrated by the evaluation and cartographic research. The southern limit of the trench was constrained by the presence of a tarmac road (illus 4). Two further trenches were excavated to the south of the road to test the possibility that features associated with Jack's Houses were present on the other side of the road. The easternmost of these two trenches was also excavated with the specific goal of recovering pottery from a large dump of potsherds revealed during the evaluation. Numbers in brackets in the following text refer to contexts numbered on the illustrations and described in detail in the archive report (Mitchell 2004).

\subsection{Results}

The footings of the southern wall and foundation trenches for the other walls were all that survived of the terrace of cottages (illus 5). The footings of the southern wall (006) were $c 18 \mathrm{~m}$ long and up to $1 \mathrm{~m}$ wide and were constructed of large sandstone blocks set directly onto the subsoil surface. A rectangular stone threshold, positioned $3 \mathrm{~m}$ from the east end of the wall, was worn and concave towards its centre. The stub of a rusted iron drainpipe was situated close to the threshold. The foundation trenches for the northern and eastern walls (003) were between $1 \mathrm{~m}$ and $1.3 \mathrm{~m}$ wide and $0.3 \mathrm{~m}$ deep. The foundation trench for the western wall was only faintly visible, having been severely truncated. A drainage ditch, containing mid 19th-century clay drainage pipes, ran parallel to the northern foundation trench. The drainage pipes terminated in a junction abutting the foundation trench, where the pipes were angled upwards and towards the house, suggesting they were rainwater and waste drainage pipes from the cottages.

An outbuilding abutted the eastern end of Jack's Houses (illus 4 ). It measured $3 \mathrm{~m}$ by $2.2 \mathrm{~m}$ and had brick wall foundations set within a $0.3 \mathrm{~m}$-deep foun- dation trench, which had been backfilled with dark brown silt. The footings of an internal dividing wall within the outbuilding were very truncated. A possible floor layer comprising a thin layer of very compact dark soil with occasional mortar flecks was present. A metal grille and fragments of 20th-century pottery were recovered from heavily disturbed demolition deposits within the interior of the outbuilding.

Two pits $(010,012)$ were discovered within the cottages. One pit (012), of $0.6 \mathrm{~m}$ diameter, occupied a central location. It was shallow and concave and was filled with black burnt material. The second pit (010) lay west of 012 , was $0.5 \mathrm{~m}$ in diameter and $0.2 \mathrm{~m}$ deep, and was partially filled with angular stones. A shallow linear trench (014), $1.5 \mathrm{~m}$ long and $0.6 \mathrm{~m}$ wide and filled with ash-rich soil, was aligned east to west across the centre of the house. A modern water pipe trench (048) containing a blue plastic pipe had been cut through the centre of Jack's Houses, most likely within the past 30 years, possibly destroying other features within the structure, and erasing relationships.

\subsubsection{Field boundaries}

Field boundaries were represented by ditches and three upstanding walls. Two of the walls (016 and 047), both aligned roughly east to west along the roadside, were situated to the east of Jack's Houses. The third (055) was located further to the north.

One of the east-west-aligned walls was situated $c 12 \mathrm{~m}$ from the eastern edge of Jack's Houses. It was still upstanding to a height of $1.2 \mathrm{~m}$ and had been built or remodelled in several phases. It was built from large volcanic boulders and smaller stones, and had a soil core which contained late 19th- and early 20th-century ceramics. This survived as a $6.2 \mathrm{~m}$-length standing to a height of $0.9 \mathrm{~m}$, although as it was better preserved on the south side it may represent the percolated remains of a former soil bank abutting the south side of the wall. The wall had been extended by the later addition of large stones to the east and west, and had been capped with mortar-bonded stone blocks and slabs. The remains of a large upright wooden post (illus 4) at the west end of the wall marked the position of a former entrance. Two postholes were located $c 2.5 \mathrm{~m}$ to the west of the post stump. Both were lined with stones and were $c 0.2 \mathrm{~m}$ wide and $c 0.3 \mathrm{~m}$ deep, and filled with dark silt.

The second wall (047), which survived as a single course of large volcanic stones, extended $2 \mathrm{~m}$ from the south-eastern corner of Jack's Houses. It had 


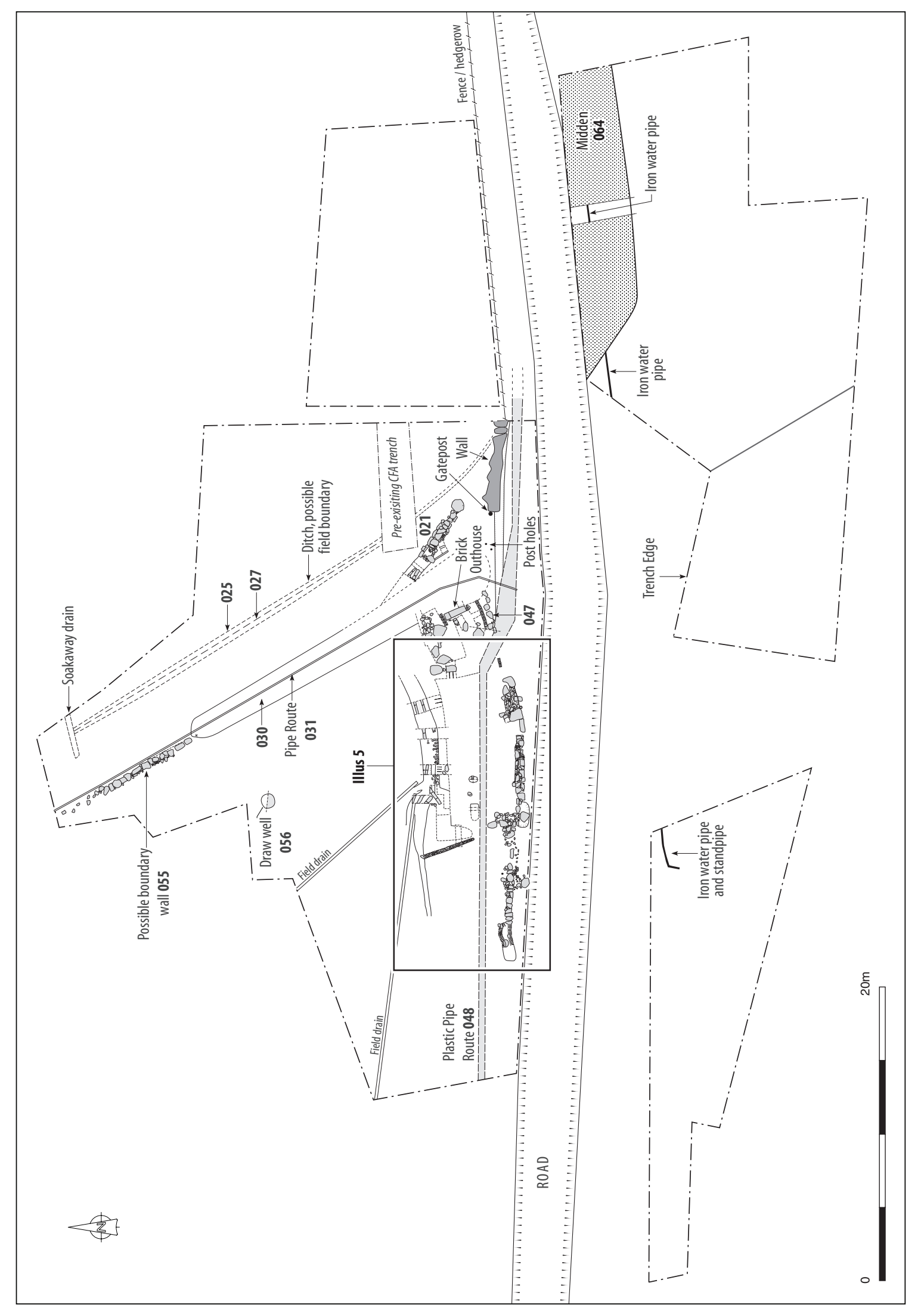

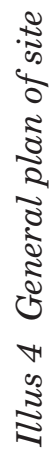




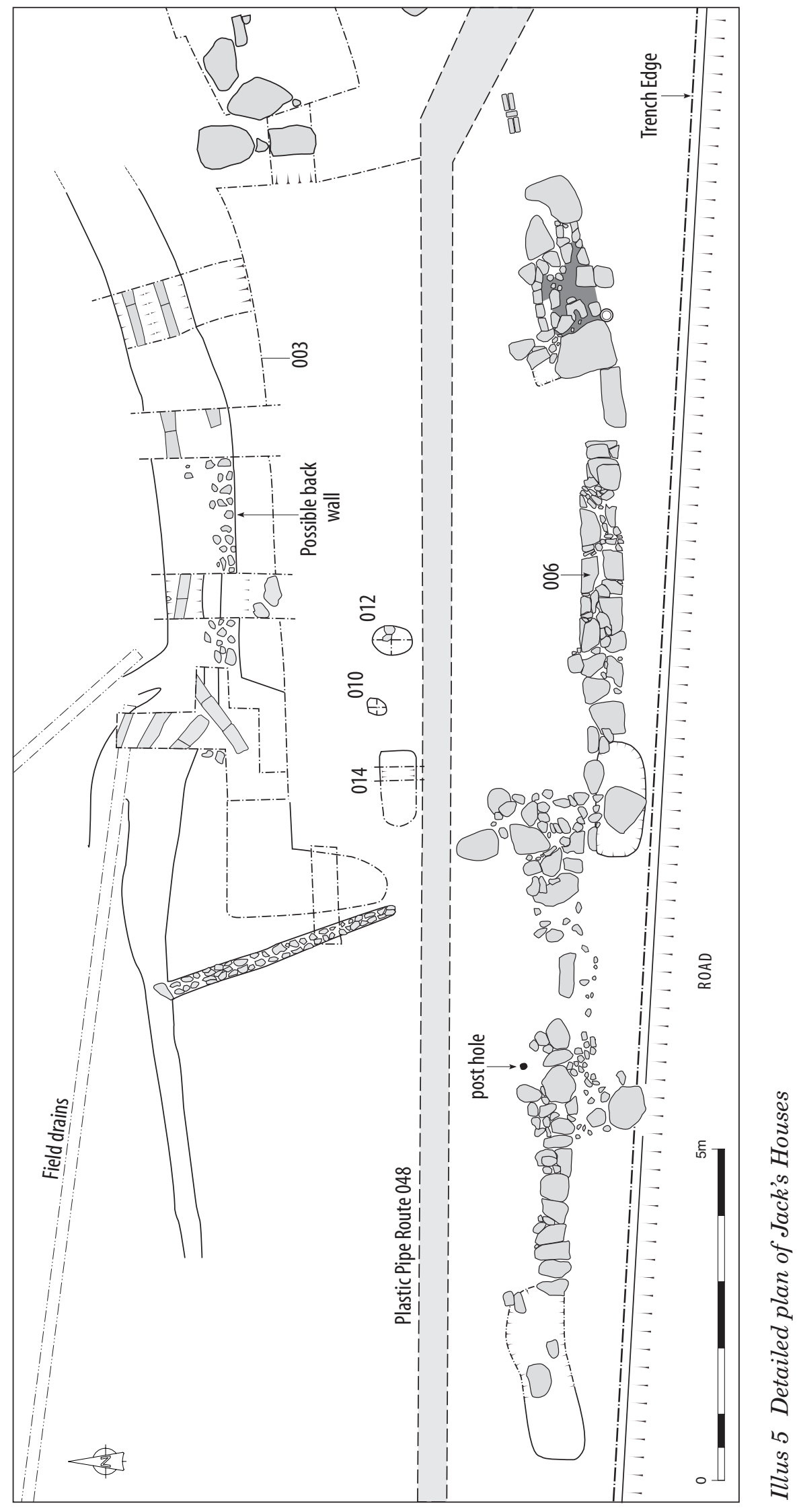


probably extended directly from Jack's Houses, but the relationship had been destroyed by the modern plastic water pipe trench.

Both walls partially overlay a field ditch, which ran from the east edge of Jack's Houses to a hawthorn hedge that defined the modern field boundary. The ditch was $1 \mathrm{~m}$ wide and $0.5 \mathrm{~m}$ deep, and was filled with dark silt containing fragments of late 19th-century pottery, glass and china. No stratigraphic relationship was revealed between Jack's Houses and the ditch, although the ditch appears to terminate close to the houses, perhaps indicating that they were contemporary, in which case the two walls post-date the building of Jack's Houses. It remains possible, however, that the ditch could have been filled in earlier in the century, before the houses were built, in which case the walls could have been constructed at the same time as the houses.

A length of wall (055) built from large sandstone blocks was revealed $c 13 \mathrm{~m}$ to the north of Jack's Houses. It was aligned north to south and was $0.8 \mathrm{~m}$ wide and $0.4 \mathrm{~m}$ high, and extended for $c 7.5 \mathrm{~m}$. It may represent the eastern boundary of the triangular enclosure depicted on the 1855 (1st edition) Ordnance Survey maps.

A linear ditch (025) aligned north to south and extending for $c 25 \mathrm{~m}$, was revealed to the east of 055 . It was $c 1.5 \mathrm{~m}$ wide and $0.5 \mathrm{~m}$ deep and was filled with re-deposited stony clay. The ditch had been re-cut by a secondary ditch (027) measuring $0.75 \mathrm{~m}$ wide and $0.5 \mathrm{~m}$ deep. It was filled with angular stones and clay and possibly represents a north-south aligned boundary.

\subsubsection{Field drainage}

Three distinct types of pre-modern drain were revealed by the excavation. The earliest type was represented by a stone culvert (021) which was aligned north-west to south-east and extended for $c$ $3.5 \mathrm{~m}$. It was $0.3 \mathrm{~m}$ wide and $0.5 \mathrm{~m}$ deep, and was built from large rectangular red sandstone blocks with unshaped sandstone lintel slabs. The culvert was cut by a clay pipe drain (031) at its north-west end. Its south-east end appeared to have been robbed out. Clay pipe drains were widely spread across much of the site, and are suspected to be of mid 19th-century date. Several soakaway drains were also present, although their dates are unknown.

\subsubsection{Draw well}

A well (056) was located $c 20$ m north of Jack's Houses, roughly where it is depicted on the 1855 (1st edition) Ordnance Survey map. It was $1.4 \mathrm{~m}$ in diameter and was lined with dressed stone blocks. The well was half-sectioned to a depth of $1 \mathrm{~m}$, at which point it became waterlogged. It was filled with damp, dark soil containing glass, metal, 19th-century pottery fragments, two leather shoes, a sock and a waterlogged wooden barrel.

\subsubsection{Other features}

A square pit measuring $0.6 \mathrm{~m}$ by $0.6 \mathrm{~m}$ and $0.5 \mathrm{~m}$ deep was discovered close to the road, midway between Jack's Houses and the upstanding field wall. It was lined with sandstone slabs and had a large flat slab in its base. It was filled with dark silt containing frequent metal and 19th-century pottery fragments. Its purpose is unclear but it may have served as a socket for an upright post.

A spread of stony compacted soil (030), aligned roughly north to south, extended $23 \mathrm{~m}$ from close to the putative gateway to the wall at the north end of the site. It measured $2.7 \mathrm{~m}$ wide and was set into a shallow cut measuring $0.3 \mathrm{~m}$ deep. It was filled with stony dark soil and was cut by a clay pipe trench for its entire length. The position and alignment of the stony soil spread relative to the gateway suggests that it may have been a track, which was later cut by the pipe trench.

An iron water pipe ran parallel to the road on its south side. It terminated on the south side of the road adjacent to Jack's Houses at a former standing hand-pump which was still present, although displaced and damaged.

\subsubsection{The midden}

A large dump of pottery and glass was situated on the south side of the road, $c 20 \mathrm{~m}$ south-east from Jack's Houses. It was $c 8 \mathrm{~m}$ by $4 \mathrm{~m}$ in extent and was up to $0.3 \mathrm{~m}$ deep. It contained large quantities of late 19 th-century refuse. The midden was sampled in its entirety. 


\section{THE FINDS}

Summary reports on the pottery and glass from the midden and waterlogged wood and leather objects from the well are included here. More complete reports and catalogues are available in the archive. Only finds from the midden and well were subjected to full analysis, following the requirements of CECAS.

\subsection{Pottery from the midden, by George Haggarty}

The original hypothesis was that the midden at Jack's Houses had served a single farmstead over a period of about 30 years and that the ceramic material represented the detritus of a single household. It would, therefore, have been an ideal group of material from which to obtain a snapshot of the social and economic status of the farm, and of the potteries supplying it.

The midden consisted of 14,666 sherds dating almost exclusively from the second, and more commonly the third, quarter of the 19th century. Residual medieval or post-medieval sherds were absent from the assemblage.

From 465 sherds - representing a minimum of 368 blacking bottles - only seven joins were noted, all from fresh breaks. Of over 1,000 redware sherds of internally white slipped dairy bowls, crocks and a few other forms - representing a minimum of $c 460$ bowls and $c 70$ crocks - only 18 joins were noted, and, of these, 11 were from fresh breaks. The horticultural redwares comprised 327 fragments, consisting mainly of flower pots and a few shallow seed trays with no joins. The agricultural redwares consisted of fragments of both flat and horseshoe extruded drainage tiles and again no joins were present in the assemblage. Some of the clay used for the extruded tiles was highly micaceous suggesting more than one source; this is unusual, as most farms and estates bought or made these locally and in a single fabric. Most of the softer earthenwares had finely abraded edges, suggesting that at some time they had been moved.

There were in total 171 shards from cups and saucers, with no joins, in late, highly developed, London shapes, of which 21 had small fragments of blue or mauve sprigs in a style common at some of the Glasgow potteries, while the rest were plain white earthenwares. The majority of the thousands of white domestic earthenware sherds came from bowls or plates with a very small presence of mugs, tureens and other forms. There were also in excess of 2,200 fragments of either single-colour sponge or polychrome-printed wares, many with banding.
Again, these were mainly bowls of various sizes, plus a few mugs.

The assemblage comprised almost as many vessels as sherds. In particular, very few of the sherds of Rockingham glazed teapots, some which had distinctive moulded covers, spouts and handles, joined.

Scottish potteries of the period such as Jamieson \& Co of Bo'ness, Methuen's of Kirkcaldy, the Clyde pottery and Bells of Glasgow are well represented in the assemblage, as are all the well-known Staffordshire makers like Spode, Wedgwood, Davenport, Rogers and Riley, and a host of lesser-known factories like Chatham \& Robinson and John Meir $\&$ Sons. Almost all the patterns attributed to the above factories are represented by just one or occasionally two sherds at the most. Samples of these identified sherds have been retained but, given the nature of the deposit, it was decided to discard the remainder.

The ceramic material could not have originated from one farm steading; the midden represented only a tiny fragment of a much larger dump (possibly 20-50 times larger). Detailed examination demonstrated that the majority of the ceramic assemblage dates from $c$ 1850-80 with a few residual sherds dating from $1820-50$.

There appears no doubt that the Jack's House midden material can only represent a tiny fragment of a dump imported to the site around 1880. It was not unusual for imported ceramic material to be used by farmers to break up clay subsoils. While this material does not represent kiln refuse, it may have been used in the same way.

\subsection{Glass from the midden, by Robin Murdoch}

The majority of the glass from the midden dates from the second half of the 19th century with a few earlier and a few later shards.

The 19th century saw dramatic changes in the design and production of utilitarian glass, particularly bottles. They evolved from individually hand-made items at the beginning of the century to mould-blown mass production by the end. Moulds had been used to shape glass for at least 2,000 years but generally for items of status. The common bottle was generally free-blown, ie without the use of a mould, irregular in finish and capacity.

Hinged two-piece moulds were introduced in the middle of the 18th century but were generally used for chemists, or later, aerated water bottles (Fletcher 1976, 33). The practice of embossing lettering on bottles started at this time. However two-piece moulds do not seem to have been used 
on wine or beer bottles at this juncture and they remained largely undecorated apart from the occasional applied shoulder seal.

In 1822, Henry Ricketts of Bristol patented a moulding machine which greatly increased output rates and, equally important, reduced skill levels required for production. Ricketts' moulder was three-piece, with a solid lower body and two hinged sections for shoulder and neck (Wills 1974, 48). After Ricketts' patent expired in 1835 many variations of the three-piece moulder were introduced and it remained the predominant tool for bottle production until around 1870 (Fletcher 1976, 133). Bottles made in three-piece moulds are easily recognised from their mould marks, especially a horizontal one round the junction of shoulder and upper body. The body itself, although nominally cylindrical, was slightly tapered to allow easy removal from the solid lower mould. The base of the mould was pushed up to release the bottle.

The three-piece moulder met its demise because it was not possible to emboss the main part of the body and be able to remove it from the mould. Therefore, in the latter part of the 19th century, the hinged two-piece mould was also brought into use for wine and beer bottles so the body of the container could now be entirely embossed if wished. A favourite arrangement, particularly among chemists or those who sold a range of bottled wares, was to have the trader's name and address embossed on one side of the bottle and a paper label with the precise contents on the other. These paper labels seldom survive the buried environment.

Three-piece moulded bottles are well represented in this assemblage and it is interesting to note the minor variations in base and lip forms. Allowing ten years or so for Ricketts' technology to become established then these bottles must represent a date range of 1830 to $c 1880$.

An interesting feature of the three-piece moulded bases in this assemblage is that they all show basering wear from repeated use. The free-blown wine bottles of the 17th and 18th centuries were used to decant wine at table rather than as long-term storage, and they were refilled from the cask or by a vintner. The presence of base wear here may indicate a continuation of that practice with these 19th-century bottles.

There is no simple way of establishing the original contents of the bottles but base-ring wear may be telling us something. The heaviest wear is on the bases with a conical kick, a shape normally associated with wine bottles, while the more rounded pimple kicks have generally slight to moderate wear. This could mean that the latter were predominantly for beer or ale and were abandoned more readily than wine, but this is simply speculation at the moment.

There are three shards from 'classic' 19th-century aerated water (soda, lemonade etc) bottles, two from 'egg' or ovate bottles and one from a 'Codd' bottle. Ovate, or Hamilton, bottles are mentioned in a patent of 1809 for the production of soda and other mineral waters, but they may pre-date this slightly (Talbot 1974, 38). These bottles had a rounded base which meant that they had to be stored on their sides so that the cork remained wet and tight fitting and therefore retained the gas suspended in the contents. This style of bottle was made until $c 1916$ and seems to have been used mostly for soda from the late 1860s onwards (Fletcher 1976, 147). Hiram Codd took out his first patent for a globe-stoppered bottle in late 1870 and by the fourth patent in 1873 he had arrived at a design which remained in use in parts of England until the 1940s. The bottles seldom survive whole because children would break them to get the glass marbles that formed the stoppers.

A characteristic of really cheaply produced 19thcentury utilitarian glass can be seen in the three shear lips in the assemblage; the small ink bottles are typical (Wills 1974, 65). Once these containers were blown, they were simply 'wetted' or sheared off the blowpipe and the rough lip left untreated. However, the generally sharp lip would bite into an oversized cork, giving a good seal (Fletcher 1976, $50)$.

The 'wine' glass base with the low conical foot is probably 19th-century. Its stem has been hand-cut into seven facets. The technique of cutting, grinding with an abrasive wheel, started in the second half of the 18th century and was extremely popular in the 19th. A close parallel to the example here can be seen in a catalogue of glass and china dating to about 1883 (Silber \& Fleming 1990, 120, pattern $5,045)$.

While the great majority of the glass in this assemblage appears to have been made in the UK, there is one bottleneck which is probably an import and possibly French.

\subsection{Organic finds from the well, by Mike Cressey}

Fifteen individual oak staves from a stave-built wooden barrel were recovered during the excavation of the well. The most complete stave measured $520 \mathrm{~mm}$ long, $150 \mathrm{~mm}$ wide and $8 \mathrm{~mm}$ thick. A piece of a wooden hoop used to bind the staves together was made from hazel. Small holes within the staves indicated that the hoop had been attached using iron nails, suggesting that the barrel had been used to store dry materials and had later been discarded down the well. Associated finds suggest that the barrel was of 19 th-century date.

Examination of the remains of two leather shoes, also recovered from the well, showed that one had a machine-stitched, composite leather sole. Iron tacks had been used to attach the heel to the sole. The inner sole had been worn through and had probably been considered to be beyond repair and hence discarded. The second shoe was represented by only the upper leather part. It had been attached to an inner sole by machine stitching, 
which was evidenced by small holes. The presence of machine stitching indicates that both shoes were probably manufactured in the late 19th or early 20th century. 


\section{DOCUMENTARY EVIDENCE}

\subsection{Jack's houses and their inhabitants over the century c 1830-1930}

While it is not possible to date precisely the construction of Jack's Houses, there is enough evidence from the census and the Hopetoun estate papers to indicate the late 1830 s as the most likely date; a valuation document from 1838 would suggest that Jack's Houses did not then exist. The first, indeed only, direct reference to Jack's Houses in the estate papers occurs in 1843, in a memorandum relative to the proposed new let of Humbie farm: 'Houses at Carmelhill and Swineburn and Jack's Houses if to be kept up - a portion of them may be kept up for workers and the others taken down.' ${ }^{1}$ We know from the 1841 census that Jack's Cottages were on the farm, and that both cottages were inhabited. The 1840s in particular seem to have been a time of improvement and new building of farm cottages on the estate. The total valuation of the buildings on the farm in 1831 and 1838 was given as £2,095, including a $£ 600$ valuation on the farmhouse. In contrast, a number of cottages on the farm were given a total valuation of $£ 160$. These were eight cottages, 'stone and thatched, communication with each other', at $£ 50$ each; two ranges of cottages at Carmelhill, 'tiled', at $£ 30$ and $£ 20$ respectively; a house at Swineburn, 'thatched', at £30; and three cottages at Swineburn, 'tiled', at £30. ${ }^{2}$ Jack’s Houses could not be among these eight cottages, as they were a terraced row, and there was no specific reference to them. So, although it may be possible that there were earlier 'Jack's Houses', it seems sensible to conclude that the Jack's Houses of this study were built some time between 1838 and 1841 .

All farm cottages on the estate at this time seem to have been in a very poor condition and in urgent need of attention. In 1846-47 considerable effort and expense was spent on the labourers' cottages at Humbie and elsewhere on the Hopetoun Estate. A letter to the Hopetoun factor from a Mr Hope Wallace (presumably a relation to the Hope family) spelled out the urgent need, and the need not to cut corners:

With respect to Humbie - the cottages are of the most wretched description - and I am very sorry that there has been any delay about renewing them. There is no doubt you will get no reduction in the estimates, and we have in Niddry a proof that there is no economy in taking the lowest offer. Of the two plans you propose - I prefer that which ensures a better class of cottage, viz. to build six new ones and to keep up some of the old ones. I do not see how we could in building new ones avoid putting up cottages of a much superior kind to the old ones, which are disgraceful. You had better see Mr Dudgeon on the subject that no time may be lost. $^{3}$

There is no way of knowing if this work included Jack's Cottages, but it is clear that the estate was spending a not insignificant amount of money. The mason work came to $£ 276$; the wright work $£ 260$; slater and plaster work $£ 104$, plus additional costs on paving and flooring the cottages, and building dykes for the gardens. The major burden fell to the estate, but the tenants (George and Robert Dudgeon) had to pay 5\% interest on any sum above an initial $£ 500$, and to keep the cottages 'in proper repair' for the duration of their lease. ${ }^{4}$

Since each cottage during the 19th-century decennial censuses (starting 1841) records different sets of occupants, it may be assumed that occupancy of these houses was not of a long-term nature. This is what we would expect, given the annual hiring of farm labour and the 'tied housing' that constituted part of that contract. However, this does not mean that occupancy changed on an annual basis. The Baxters, one of the first families recorded inhabiting Jack's Houses, were still at the same address in 1845 , while the Anthonys, who were resident in Jack's Houses in 1891, were to be found at nearby Humbie Farm cottage in 1901. Over the five censuses, 1841-91, the occupations of the inhabitants were Agricultural/Farm Labourer, Blacksmith, Coachman \& Gardener, Quarry Labourer, OutWorker, Roadsman, Servant, Shepherd and Wright. These occupations reflect the economic needs of the farm and its proprietor at various times. There were two quarries located at Humbie Farm, though not tenanted by the farmer; an old lime quarry dating back to the early 17th century, and a sandstone quarry which produced a renowned stone, used in the construction of Newliston House and the Glasgow Stock Exchange, and which may have produced the stone for Jack's Houses also. ${ }^{5}$ Within the estate papers there is a somewhat cryptic reference to the quarry being approached in the 1830s with the possibility of 'exhibiting stones ... to be considered for the new Parliament Buildings'. ${ }^{6}$ The demand for blacksmiths seems to have been directly related to the smithy on the farm.?

Using the place of birth on the census form as an indication of the region from which the inhabitants were drawn, it appears that most came from the surrounding Lothians area. This was particularly true for the more skilled workers, viz. blacksmiths and wrights. A visit to the old kirk cemetery at Kirkliston showed that the surnames of 'Brash' and 'Borthwick' 
featured prominently in the locale. However, some occupants were born in the Borders, Aberdeenshire and Ireland. This is in accordance with the historical migratory patterns of agricultural workers and other specific employment factors such as the construction of the Union canal in 1818-22, which used much Irish labour. ${ }^{8,} 9$

Though it cannot be determined which set of occupants inhabited which dwelling from the earlier censuses, as they do not specify the number of windowed rooms per cottage until 1861, it is clear from the number of individuals recorded in families that overcrowding was a fact of life. In 1841 the Baxter family may have inhabited the cottage with one or two windowed rooms; either way, it seems a tight squeeze. However, we know that in 1861 Patrick Curron, an agricultural labourer, occupied the one-window house with his extended family, comprising eight individuals in total, five adults and three children.

In an attempt to flesh out the information in the censuses, an effort was made to link families from census to census and track life events such as births, deaths and marriages through the civil register (only possible with the introduction of compulsory civil registration). It was not possible to track some occupants from the earlier censuses due to the common nature of the names and because of the lapse of 40 years between 1841 and 1881 , the first census searchable by name. The recordlinkage method is explained in more detail in the Appendix.

The poor or labouring population leave little by way of documentary evidence of their lives. Such records are generally the preserve of the wealthy. A case in point is the early Valuation Rolls, which listed neither Jack's Houses nor their inhabitants. The bias towards those with property is demonstrated by the assessor's presentation, which amounts to a list of properties in the parish arranged alphabetically by owner. Workmen's cottages were not given individual addresses and their inhabitants were ascribed the collective term 'sundry'. It is only towards the end of the 19th century that Jack's 'Cottages' are identified in the Valuation Roll.

Although one would not expect the inhabitants of Jack's Houses to have left much in the way of personal wealth or possessions, a search of 19 thcentury inventories produced one instance, that of Ann Borthwick who was listed in the 1861 census at Jack's Houses; Ann was then 29, married with three children. Both she and her husband James were agricultural labourers. When Ann died in Kirkliston in 1890 she was a widow, having been predeceased by her husband five years previously. Ann's inventory reveals that she left $£ 4712 \mathrm{~s} 9 \mathrm{~d}$, which comprised $£ 3212$ s 9 d in the National Security Savings Bank of Edinburgh, household furniture and effects valued at $£ 9$, and $£ 6$ death benefit from the Kirkliston Funeral Society. By contrast, an inventory of one of the tenants of Humbie, George Dudgeon, who died in 1876, brought in a total of $£ 3925 \mathrm{~s} 9 \mathrm{~d}, £ 88$ of which was cash, $£ 5$ personal effects and the rest in stock of the Bank of Scotland and money in the Clydesdale Banking Co. of Edinburgh. Another inhabitant of Jack's Houses was Lewis Gilbert, a farm labourer, who lived there in 1851. Lewis had a son, William, who was not listed as living with his parents in 1851 , but who became a farmer in his own right and who, when he died in 1894 , left a personal estate of $£ 1,48912 \mathrm{~s} 6 \mathrm{~d}$. Dwarfing all of these, however, was the wealth of the landowner. The inventory of John Hope, Earl of Hopetoun, who died in 1824 , amounted to $£ 63,809$ $3 \mathrm{~s} 6 \mathrm{~d}$, comprising sums from rentals and feus, debts owed and mining concerns in the Leadhills; his interests stretched from Arniston Hall in Midlothian to arable land in Dumfriesshire. ${ }^{10}$ This is not an accurate reflection of Hope's true wealth, as the inventories only include 'personal' wealth, not 'real' wealth, ie land and property.

Another contrast can be drawn from the fate of Mary McRiner, who inhabited the one-roomed house in 1891 with her husband Peter, a roadsman. Her husband was then aged 64, and Mary was 62 years old; no other family lived with them. Peter died of bronchitis in 1896 at Overtoun, Kirkliston. The 1901 census shows Mary residing with her sister at Overtoun, both in receipt of Parish Relief. Shortly thereafter, in June of that year, Mary died, aged 74, of cardiac disease, dropsy and heart failure. This was not the only example of the poverty of those who lived in Jack's Houses, as two other inhabitants died in the poorhouse (see Appendix).

Jack's Houses were largely typical of the cottage accommodation that was provided for farm workers and their families throughout Scotland from the early 19 th century. Until that date the usual house was 'a primitive erection of four walls of stone, or a mixture of turf and clay and stone, thatched with turf or straw, without chimney and often without windows, the floors of clay'. Thereafter, more substantial properties were constructed, 'stone and lime walls were built, two rooms were provided with a proper partition between, floorings and ceilings were added, and the internal finishings of the rooms attended to'. 11 The farm cottages tended to be built in pairs or rows, usually the site being selected to economise on land and/or to house the occupants close to their work. Jack's Houses was located at one extremity of Humbie Farm, along what is identified on one map as the parish road, and between two fields: Jack's Park North and Jack's Park South. The names of the fields explain the sobriquet of the cottages, but, unfortunately, it is not known why the fields were so titled originally. Including their 'yards' or gardens, the physical area of Jack's Houses comprised 0.142 acres. ${ }^{12}$

Although the Royal Commission on Housing in 1917 reported that one-roomed houses were very rare in agrarian districts, we know from the census (see above) that one of Jack's Houses was such a dwelling. While we do not have any plans or descriptions of Jack's Houses themselves, there 
is an architectural drawing of the nearby 'Humbie Farm Cottages' dated 1904. This plan was drawn up by the Hopetoun Estate when 'additions' were being made to a terrace of four cottages, which still stands today. The plan reveals a very basic internal layout of 'Kitchen', 'Room', 'Lobby' and 'Pantry', with one cottage having an extra 'Cupboard'. In addition, each cottage had its own coal shed attached, and there was one 'Ashpit' and one 'E.C.' (earth closet) shared between two cottages. The 'additions' being made seem to have been an extension to the 'Room' in each cottage, rather than the construction of an additional room. In one case it is possible to identify the dimensions of the 'Room', which was 12 feet 3 inches by 14 feet $(3.73 \times 4.27 \mathrm{~m})$. Neither the 'Pantry' nor the 'Lobby' constituted a room as such; the two rooms of the cottages were the 'Room' and the 'Kitchen', with the latter being the larger. ${ }^{13}$

This style of housing was largely determined by the agricultural improvements of the late 18th century, which also dictated the nature of the tenancy and occupancy. With enclosure and the removal of the subtenants, the farmers needed more hands and also more regularly employed workers. This labour arrangement was crucial to the efficiency of 19thcentury agriculture in Scotland. ${ }^{14}$ Cottages had to be built for the married men, who were employed on six-month or yearly contracts and who brought their wives and children onto the farm. A particular aspect of Scottish farming was the heavy use of female labour. ${ }^{15}$ Wages were paid partly in cash and partly in 'allowances', that is, from the produce of the farm, and the cottage, provided rent and rate free, was part of the contract. In Linlithgowshire or West Lothian the hiring system was yearly, with the contracts made in February and the move to a new cottage on Whitsunday. The average wage of a farm servant in this area was estimated in 1914 to be $£ 13 \mathrm{~s}$, comprising $£ 11 \mathrm{~s}$ in cash and $2 \mathrm{~s}$ in allowances. This placed West Lothian in the top six wage-earning counties of Scotland, and, alongside Edinburgh, the county with the lowest level of allowances. ${ }^{16}$

The demand for labour was determined by the type of agriculture and the size of farms. The vast majority of Scottish farms were small. A survey conducted in 1906 found that fully 70 per cent of all farms had an annual valuation of under $£ 50$. On a county basis, West Lothian was in the middle range, which still meant that very few farms were in the high-rated category (ie over £300). ${ }^{17}$ Humbie, however, was definitely a high rental farm; the Valuation Roll for 1909-10 gave the rateable value, or annual rental, as $£ 7206 \mathrm{~s} 1 \mathrm{~d} .{ }^{18}$ This meant that the labour needs of Humbie would be different from those of a small farm. According to John Frew, the County Sanitary Inspector for Linlithgowshire, most farms were small, between 100 and 120 acres, a large proportion of which would be worked by the farmer and his family. When they did need labour, they preferred single men, indeed they often stipu- lated this. Frew explained the logic of this decision: 'The older people get, the older-fashioned they get.' 19 But Frew could not have been unaware that single men did not need a cottage and so the farmer would have been spared that expense. On a larger farm, such as Humbie, however, married farm workers, and hence cottages, were necessary.

While the worker got his accommodation from the farmer, the actual cottage was the property of the landowner. This gave a divided responsibility for maintaining the cottages, which could encourage each party to try and avoid the burden of repairs. Minor repairs were meant to be the responsibility of the farmer, while the landowner was to see to structural repairs. It may have been the case, as the 'additions' to the Humbie Farm Cottages in 1904 suggest, that the situation in larger farms and estates was better. Nevertheless, the condition of Jack's Houses was likely to have been similar to most farm cottages. All cottages had gardens of between 100 square yards and one eighth of an acre, though Scottish farm workers tended not to grow flowers. Potatoes were ubiquitous and, along with other vegetables grown, an important part of the family income. ${ }^{20}$

The interiors of the cottages were very basic; each new occupant was likely to personalise the accommodation only by the little personal furniture they had and by papering or painting the walls. Baths were unknown in farm cottages: indeed the Royal Commission on Housing debated whether or not the working class could be taught how to use them. There was no internal plumbing in the cottages, but, at least in West Lothian, the water supply was just outside. All farm cottages suffered from damp. Often this was to do with the location; they tended to be built on an available space without consideration of the consequences. In addition, there was usually no internal lining; the plaster was put straight onto the bare walls. Whatever the causes, complaints about damp were more or less universal, as was the chronic rheumatism that farm workers suffered from. ${ }^{21}$ The evidence for West Lothian given to the Commission was consistent with the national pattern. ${ }^{22}$ The incidence of respiratory conditions as a cause of death among the sometime inhabitants of Jack's Houses suggests that these cottages were no different to the norm, and the fact that they were condemned in the early 1930 s suggests that they might indeed have been inferior to most.

\subsection{A history of Kirkliston parish, focusing on the 1830s and'40s}

Today the area that was the Parish of Kirkliston is part of the City of Edinburgh, but it was, for most of its history, divided between the counties of Midlothian and West Lothian, or Linlithgow. The main part of the parish, including the town of Kirkliston and - of most concern to us - the lands 
of Humbie, were located in the latter county. While agriculture (Humbie remains a working farm today) provides historical continuity with a much earlier period, Kirkliston has experienced major social and economic changes over the last two centuries. Canal-building in the early 19th century, followed by the railways, the rise and fall of the shale mining industry, the construction of the Forth rail and road bridges, the M9 motorway, the building and continuing expansion of Edinburgh airport, have all made their impact on the local economy and physical landscape.

The ecclesiastical history of Kirkliston provides the lengthiest unbroken link in the area's history. The parish church of Kirkliston was built around the end of the 12th century and was dedicated by the Bishop of St Andrews on 11 September 1244. The earliest written records of agriculture, however, date from the later 17th century only. Crops grown then include bere (or bear, barley), oats, wheat and peas; horses, cattle and sheep were kept, and liming, manuring and the rotation of crops were known about and practised. While the traditional system of 'infield' and 'outfield' cultivation continued in some parts of the parish until the later 18th century, 'improvement' was being progressively pursued from early in the century. The most famous figure in this respect was Lord Stair, who inherited the estate of Newliston and is acknowledged as being the first in the area to replace the traditional ox plough with one pulled by two horses. He is also credited with being the first person in Scotland to have had turnips and cabbages planted in open fields. ${ }^{23}$

Improvement was not, however, simply imposed from the top by the landowners. The tenant farmers played a crucial role also, especially once the initial structural changes had been introduced. ${ }^{24}$ In Kirkliston this meant men such as John Allan of Loanhead and George Reid, tenant of Humbie, who made marked improvements in draining the land. Around 1767 most of the land of the parish was enclosed, with the old strips or rigs being consolidated into fields divided by trees, hedgerows or dykes. Longer leases were granted by the landlords to the tenant farmers, though by 1839 (the date of the New Statistical Account) 19 years was the general term. At this same date many farm cottages in the parish were renovated or improved. It is evident that this was the period of tenure enjoyed by the Dudgeons as shown, for example, on the new let agreed for Humbie in $1925 .^{25}$ Lets were, however, open to re-negotiation during the stated period and new agreements could be reached before the term was finished. In 1838 a memorandum regarding a new lease for Humbie was written up, and a copy sent to Professor Low of Edinburgh, who was contracted to produce a report and effective valuation of the farm. ${ }^{26}$ It is worth quoting from this report, since it reveals both the recognised worth of the farm and the need for mutual co-operation between landlord and tenant:
The farm is in excellent order, but a considerable portion of it, as you are aware, is not of a quality to admit of a high rent and can only be kept productive by a liberal expenditure on the part of the tenant. I very much approve of the proposed arrangement with the present occupier and it is of the first importance to the interests of the farm that the improvements now in progress with respect to draining and otherwise should proceed without interruption. I have no hesitation in saying that the manner in which this farm has been managed is an example to the country. ${ }^{27}$

Humbie Farm, as indicated above, was part of this process of improvement. It appears likely that Jack's Houses were built in 1839, the same year that the new lease was drawn up for the farm. ${ }^{28}$

It is likely that the farm area was originally within the ecclesiastical lands of Kirkliston, though by 1500 it was in the possession of the Liston family. The Liston and Hamilton families were connected by marriage and farmed the lands throughout the following century, before the latter became sole proprietor. Humbie then passed to the earls of Wintoun, before becoming, in 1678, the property of the Hope family; firstly John and then his son Charles, the first earl of Hopetoun. George Reid, whose Covenanter ancestor Alexander is buried in the churchyard of Kirkliston, became the tenant during the 18th century, and the farmhouse of Humbie was built around 1782. Reid's daughter, Elizabeth, married Alexander Dudgeon and it has been the Dudgeon family who have farmed Humbie since the 19th century. It would appear, from the Hopetoun estate papers, that a more precise date for the building of Jack's Houses may be 1839 , the same year that a new lease was drawn up for Humbie Farm. ${ }^{29}$

The first Statistical Account of Kirkliston was written by John Muckarsie, assistant to the minister, in 1792-93 and he remarked that there had been 'great changes of landholders here as in all the parishes of Scotland'. The New Statistical Account of Kirkliston (1839), written by the local minister, Rev. Tait, identified nine men as the chief landowners, the most significant being the earl of Hopetoun, who owned more than 40 per cent of the valued rent of the parish (£12,846 18s Scots). The same source identified 30 farms and, in his evidence to the 1844 Poor Law Inquiry, stated that the size of these ranged from 50 to 500 acres. Fifty years previously Muckarsie had commented that most farms were between 100 and 200 acres, with only three or four farms between 300 and 500 acres. A plan of Humbie Farm, drawn up in October 1843, shows the total acreage then to have been 644 imperial acres (or 510 Scots acres), which would suggest that Humbie was one of the larger farms of the parish. ${ }^{30}$

In his census of 1755 , the first census undertaken in Scotland, the Rev. Dr Alexander Webster gave the population of Kirkliston parish as $1,461 .^{31}$ The Statistical Account, written almost 40 years later, gave the inhabitants as 1,504 individuals and 352 
families. The first census revealed a population of 1,674 in 1801, and in 1811 this had risen only fractionally, to 1682 . Over the next decade, however, a more substantial increase occurred so that in 1821 the population had reached 2,213 , the reason being the influx of labourers working on the construction of the Union Canal between 1818 and 1822. The impressive aqueduct these men built over the River Almond remains a significant local landmark, as does the later Almond Valley railway viaduct built in 1842. In 1831 there was little change in the population, which had increased by only 42 , to 2,265 . Another surge thereafter brought the population to 2,989 in 1841 , presumably due to the building of the Edinburgh-Glasgow railway line, which was completed in 1842. The temporary nature of this second influx of labourers is shown by the subsequent sharp fall in population to 2,029 by 1851 . For the next 20 years there was little change, but by 1881 the number of inhabitants had expanded to 2,580. A much greater rate of increase, however, occurred over the next ten years, when an almost 50 per cent increase took the population to a new high of 3,737 . Behind this expansion lay the development of the shale oil industry and the building of the Forth Railway Bridge. James 'Paraffin' Young first extracted shale oil in the district in 1858 and over the next hundred years this industry would play a significant role in the life and economy of Kirkliston. Another significant jump in population between 1901 and 1911 (from 3,904 to 5,298) is explained by the rapid expansion of the shale industry in these years, which brought a large number of labourers from Northern Ireland into the area. The opening of St Philomena's Catholic Church in 1903 is indicative of this immigration. For the next 50 years population figures were more or less static, the census of 1961 giving a figure of $5,242 .{ }^{32}$

The first Statistical Account divided the population of the parish into two 'classes'; apart from the three resident heritor, or landowning, families, the people were labelled either 'farmers' or 'mechanics and servants'. The farmers, 'being almost wholly on the same level, live together in the most intimate habits of friendship and hospitality'. Muckarsie commented favourably on the 'increasing civilization of manners', and how the farmers had foregone the pleasure of conducting their business and amusement in the public houses of the parish; now they entertained at home 'in the family style'. On the other hand, he could detect no great change in the 'morals of the common people'. Because of the 'equality of the farms and the want of manufactures', it was effectively impossible that any mechanic or farm servant could rise to become a master in his own right. ${ }^{33}$

Writing in the New Statistical Account nearly 40 years later, Rev. Tait presented a largely unchanged picture. The developments in farming had continued steadily and 'at the present time there is perhaps no parish in Scotland, which, in respect of the system of husbandry pursued, is further advanced in improve- ment, or more distinguished by the excellence of its management'. The building of the Union Canal had been done mostly by labourers from Ireland, 'many of who became, from that time, settled inhabitants'. This in-migration did not, however, alter the social structure of the parish, as the Irish who stayed once again became workers on the land. In his evidence to the Poor Law Inquiry of 1844, Tait stated that the parish had no manufactures, no colliers or miners, and he did not give an estimate of the number of agricultural labourers because, 'the population is almost wholly agricultural' ${ }^{34}$

Like his predecessor, Tait bemoaned the 'low price of spiritous liquors' (the original Kirkliston Distillery, still in existence today, was built in the early years of the 19th century), though unlike Muckarsie, Tait did not repeat the call for a combined solution of raising the price of spirits while making ale 'a more palatable and substantial beverage'. While complaining about the failings of the labouring classes to save sufficiently 'from present income a provision for future want', he did recognise a 'distressing amount of poverty', especially in the village of Kirkliston itself, 'where some of the houses are little better than Irish cabins'. A Friendly Society had been established in 1798, and two other benefit societies had been established subsequently; these paid out an annual benefit to members, while the former operated as a genuine insurance against sickness, unemployment and old age. Notwithstanding these efforts at mutual assistance, Tait could not see how the poor could be helped 'without also multiplying the demands for future relief'. This last statement reveals Tait's sympathy with the views of the Rev. Thomas Chalmers on the necessity of denying any legal right of the poor to support, in order to avoid 'encouraging pauperism'. ${ }^{35}$

The Disruption of 1843 saw the majority of ministers and kirk elders follow the charismatic Thomas Chalmers out of the state Church of Scotland, into the new voluntary Free Church of Scotland. This schism, led by a man who, ironically, desired a state-funded Church, had major repercussions, both theologically and socially, for Scotland. In Kirkliston there was immediate support for the new congregation, with a Free Church opening its doors in Kirkliston High Street in May 1843. Traditionally, the Free Church has been identified as the more 'democratic' body, in that more of its members were from the lower orders than was the case in the Church of Scotland. That interpretation has been revised, particularly for urban congregations, but it appears to hold true for Kirkliston. The earliest Communion Roll for Kirkliston Free Church reveals that both of the families then inhabiting Jack's Houses were members: John and Agnes Baxter, and William Gibson and his wife. ${ }^{36}$ Other names on the Communion Roll from 'Humbie', which presumably meant other farm workers, were: Fairlie, Kirwood, Lawrie, Potter, Stewart and Tod. A George Sharp from 'Kirkliston', was also on the Communion Roll, and this may have been either the John Sharp 
who inhabited one of Jack's Houses at the time of the 1841 census, or his eldest son, who was 25 in $1841 .^{37}$ One cannot, however, say that all agricultural labourers identified with the Free Church, as the Baptismal Register of the Church of Scotland contains four baptisms between 1863 and 1923 of children born to parents who resided at Humbie. ${ }^{38}$

It was the great debate over the efficacy of the Poor Law, and whether the poor and the unemployed should have a right to statutory relief, which brought about the 1844 Inquiry. The Disruption of 1843 , which split the Church of Scotland and saw the formation of the Free Church, threw the existing system of parish relief into further crisis. The evidence collated by the Poor Law Commissioners allows us a little more detail (alongside the first and second Statistical Accounts) on the lives of the labouring classes or common people, ie the sort of people who inhabited Jack's Houses. ${ }^{39}$

The local arrangements for the relief of the poor were put under tremendous strain by the establishment of a rival congregation in the parish; the Free Church had opened its doors in Kirkliston High Street in May 1843. For many years the heritors had paid an annual voluntary contribution based upon valued rents. About 1839, however, an agreement was reached between the heritors and the kirk-session whereby the former would continue to provide for those already on the poor's roll, while the latter would provide for new additions to the roll; in 1842 the heritors contributed $£ 200$, while the church-door collection amounted to about $£ 40$ plus an additional $£ 15$ collection for coals for the poor.

The Kirk Sessions Minutes do not mention any of the identified inhabitants of the houses; however, many bearing the same surname (eg Brash, Borthwick, Anthony, Sharp and White) were in receipt of allowances. Lord Hopetoun and the Dudgeons, who tenanted Humbie and Almondhill farms, contributed to the coffers on an annual basis. For example the decade 1854-64 saw Hopetoun donating $£ 418$ s $10 \mathrm{~d}$ per annum and the Dudgeons 10 s each per annum. This arrangement, as well as a similar one for the payment of the parish schoolmaster's salary, was written into the farm lease. ${ }^{40}$ Hopetoun also gave additional relief of oatmeal to the deserving poor who lived on his property, the Kirk-Session deciding who would qualify. He did not, however, see fit to contribute to the annual collection to provide coal for the poor of Bathgate. ${ }^{41}$ In keeping with the paternalism through which much of the landlord's authority was maintained, Hopetoun did pay pensions to long-standing servants on his estate. For instance, in 1847 'Widow Erskine' received £3 as her half-yearly allowance, though deducted from this was $7 \mathrm{~s} 3 \mathrm{~d}$, being the cash value of the meal that she was given. ${ }^{42}$

The usual allowance for an individual pauper was $4 \mathrm{~s}$ per month, though a wholly bed-ridden person could be given $8 \mathrm{~s}$. A couple of specific cases were detailed by Tait, and these are worth referring to since they appear to echo some of today's welfare concerns. There was 'an idiot' on the roll, a woman who was looked after by her brother, who received an allowance of $3 \mathrm{~s} 6 \mathrm{~d}$ for his efforts. There was also a widow with three children under ten years of age, who received $5 \mathrm{~s}$ per month, but she was expected to supplement this with wages earned as an outdoor labourer; when at work her children were looked after by her neighbours. Tait stated that it was 'rare' for single women with illegitimate children to be given aid, though women deserted by their husbands were relieved. The minister added that such desertion was, and always had been, very uncommon in the parish.

In 1842 there had been 15 persons receiving occasional relief, especially during winter, while the number on those of the permanent roll was 52. Of the latter, women outnumbered men by more than two to one (36 to 16 respectively), while a similar number (35) were over 60 years old. Despite the lack of any legal entitlement of the able-bodied poor (ie the unemployed) to relief, aid was given to men who were temporarily sick and, more controversially, $£ 17$ had been spent on helping the unemployed during the winter of $1842-43$.

At the 1844 Inquiry Tait also gave some detail relating to general living conditions, which supplemented his Account of the parish in 1839. He stated that the average wage of hinds or servants employed in farming was $£ 16$ for men and $£ 6$ for women, the latter figure including 'victuals'. Five years previously he had given the wages of farm servants as £26-£27 per annum 'on average, all things included'. One must assume that the higher figure incorporated allowances such as food and rent. Although payment in kind became increasingly less significant in West Lothian, it still remained part of the agricultural wage well into the 20th century. ${ }^{43}$ Able-bodied day-labourers in farming got $9 \mathrm{~s}-10$ s per week, which appears equal to the permanently employed farm servants such as a ploughman. The day-labourers, however, would not be employed every week of the year, so these amounts are not strictly comparable.

Artisans averaged 10 s per week also, or at daily rates: wrights $2 \mathrm{~s} 6 \mathrm{~d}$; masons $3 \mathrm{~s}$; slaters $3 \mathrm{~s}$ or $3 \mathrm{~s} 6 \mathrm{~d}$, while, 'smithy work is frequently contracted for, and often charged at a price per article'. More precise figures can be obtained from the Hopetoun estate papers, though these do not refer to the tenanted farms but to those workers employed directly by the estate. For instance, in 1847 John Cockburn, a grieve, was paid an annual wage of $£ 84$, plus 6.5 bolls of meal valued at $£ 9$ s 6 d. Robert Mitchell, a forester, was paid $£ 50$ per annum cash. Andrew Dick, a herd, was paid half a year's salary of $£ 15$, minus $£ 516$ s worth of meal. Robert Allan, a carter, was paid $£ 18$ per annum, minus meal valued at $£ 11$ 19s 3d, with a further deduction of 10 s for house rent, leaving a cash total of $£ 510$ s $9 \mathrm{~d} .{ }^{44}$ This evidence indicates the substantial variances in wages, the significant contribution of payment in kind, and the difference in that some workers were 
effectively given a bonus through the provision of meal, while for others it represented a reduction in their money wages.

Unfortunately, Tait gave no response to the question about the diet of the local population, but he did give some information on prices and rents. Potatoes cost 10s per boll of four cwt, and coal cost 10 s per ton. Farm-servants generally had no difficulty getting accommodation in the parish, and Tait could recall only a couple of instances of men moving to towns on this account. The usual rent for a labourer's cottage was $£ 2$ per annum, and the cottages had gardens attached.

Tait considered that 'the people seem to be generally alive to the benefits of education'. Nearly all young people between the ages of six and fifteen could read, and 'a large proportion' of them could write also. Very few aged over 15 could not read, and most could write 'in a certain degree'. Since the parish of Kirkliston covered 5.5 miles by 4.5 miles, no one was so remote they could not attend a school. Apart from the parish school, which had 90 pupils, there were four other schools in the vicinity. One was for girls who were taught sewing as well as 'the ordinary elements of education'. In contrast, the curriculum of the parochial school comprised reading, English grammar, writing and arithmetic, geography and Latin. The fees were paid quarterly in advance and could, in total, amount to $£ 50$ per annum. The heritors provided a salary, house and garden for the teacher, who also earned an additional $£ 20$ per annum in his other roles of session clerk, clerk to the heritors and Statute Labour commissioners. All pauper children were 'instructed in the common branches', ie reading, writing and arithmetic. While the children of the poor had their school fees paid from the parish funds, it was recognised also that the labourers could find it difficult to find the money when 'work was scarce'; in such circumstances the Kirk-session could pay half the school fees.

In recent years historians have begun to use criminal records as potential sources for wider social history. ${ }^{45}$ An examination of the Advocate Depute records of serious crime in the 19th century reveals that Kirkliston, while hardly a hot-bed of vice, had its fair share of criminal acts. A few of these demanded some further attention. In 1871 a James Anthony, miner and native of Kirkliston, was tried at Stirling for the crime of bigamy. ${ }^{46}$ In 1871, Jane Baxter, a washer and cleaner and native of Kirkliston, was tried at Glasgow on a charge of theft and previous conviction. ${ }^{47}$ The interest in these two cases is because the accused shared the same names as sometime residents in Jack's Cottages. It is not possible directly to link these individuals to those identified in the census, but it is likely that they were related at least. In the case of Jane, she had made strenuous efforts to disguise her true identity; at her trial she was charged under her own name and eight aliases. Her attempted subterfuge did not help and she was sentenced to seven years' penal servitude. James was also found guilty, but received only nine months' imprisonment.

Perhaps a more distinctively rural crime was poaching, and two cases concerned Humbie Farm. In 1827 , and again in 1830 , poachers were caught by the Earl of Hopetoun's gamekeepers, Henry Logan, John Martin and Archibald Dick; on both occasions at exactly the same spot. In 1827 the accused were George Binnie and Robert Orrock, a wright and his journeyman respectively, and natives of Kirkliston. While there is no record of any verdict against Binnie, which suggests he either was not charged or absconded, Orrock was found guilty in terms of his own confession, and got two months' imprisonment. ${ }^{48}$ The case in 1830 involved Walter Omit, Peter Taylor and John Young, all of whom were employed as quarrymen at Humbie Quarry. All were found guilty and were given the same sentence of five years' probation and $£ 100$ penalty. ${ }^{49}$ As poaching was a transportable offence, all five would appear to have got off relatively lightly, perhaps due to their having no previous convictions, or an understanding by the authorities that taking game was simply part of rural life.

This, then, was the world that the early occupants of Jack's Houses would have inhabited. In many respects it changed little over a century. Over this period, and indeed beyond, both the farmer and the landowner remained the same. The tenancy of Humbie stayed within the Dudgeon family, and the farm remained the property of the Hope family; the formal change in ownership from the Marquis of Lothian to the Hopetoun Development Company in the inter-war period was likely an early example of reducing exposure to death duties. ${ }^{50}$ While the inhabitants of the cottages changed on a regular basis, this was part and parcel of the labour system and the hiring contract. It was not difficult for people to leave the land, and the record-linkage undertaken in this study shows movement to Kirkcaldy, Glasgow and Edinburgh. Most, however, moved only short distances and remained in or near Kirkliston (see Appendix).

The inhabitants of Jack's Houses were mostly agricultural workers living in tied cottages, which, along with the yearly hiring, designated them as 'farm servants'. Historically, such workers have often been regarded as deferential. The work of Howard Newby has been influential in seeking to explain why agricultural labourers have remained low-paid and resistant to trade union organisation. ${ }^{51}$ Newby's approach has been to look beyond the economics of agriculture - the price of products determining wages - to a more sociological approach exploring the social relations between farmer and worker. However, Newby's original research was based on East Anglia and, whatever explanatory significance it has for the English experience (and there have been English critics of Newby ${ }^{52}$ ), it does not appear to have much, if any, relevance to Scotland. Carter, writing about the north-east, and Anthony, writing about East Lothian, have found a marked absence of 
deferential behaviour and attitudes among Scottish farm workers. ${ }^{53}$ These authors emphasise the independence of such workers, who were conscious of their skills and who could easily avoid employers with a bad reputation. More generally, it was not difficult to leave the land in 19th-century Scotland, which encouraged farmers to maintain wages and conditions. There was considerable social mixing between workers and farmers, through Church and at school. Thus, while farm workers may have recognised the inequality of the employer-employee relationship, they did not regard themselves as socially inferior.

There has been no similarly detailed work done on West Lothian but, while some of the peculiarities of the area have been mentioned above, one would not expect the broad picture to have been significantly different. The farmer of Humbie at the time of the excavation, George Dudgeon, grew up there in the $1930 \mathrm{~s}$ and $1940 \mathrm{~s}$, and recalls that most of the workers employed came from the Lothians, Fife and Perth. Since these areas had similar types of farm, such workers were familiar with the largely arable needs of Humbie. ${ }^{54}$ In his father's and grandfather's time, most of the hiring of the labourers took place annually at the Dalkeith Hiring Fair, though this was later supplemented and eventually replaced by simply placing adverts in the Edinburgh Evening News and the Farming News. Recruitment through word of mouth continued to play a role. While the contract was for a year, sometimes individuals would stay from five to ten years, a decision which was dependent upon their relationship with the farmer. Temporary workers came locally, such as miners from Winchburgh, and from Ireland for picking the potatoes. It has been argued that the system of tenancy encouraged social mobility, as the capital outlay needed to secure a tenancy was much less than under the system of owner-occupation of farms. In Scotland, it was only after the First World War, and more so after World War Two, that there was a substantial move by tenants to purchase farms. ${ }^{55}$ It is interesting that the Dudgeon family only purchased Humbie, and did so reluctantly, as late as 1980 , when death duties forced the Hopetoun estate to sell some of its land. For George Dudgeon, the displacement of the tenant farmer is regarded with some sadness as, in his view, the best relationship was where landlord and tenant worked to their mutual benefit: 'If the landlord is a good landlord he will look after the tenant and the tenant will appreciate that and work the farm accordingly. The landlord has no responsibility as regards the farming of it if he has a good tenant; he collects the rent which, hopefully, is a fair rent to him and the tenant. And I've seen so many estates bust up when a tenant dies and they take the land back into their own hands, and they won't re-let it and, quite honestly it's not as well farmed as when the tenant farmers were in it.' Referring directly to his own family's situation, Mr Dudgeon continued,
'Hopetoun estate was always a pretty fair estate ... it wasn't a ridiculously high rent, but it wasn't a low rent. ${ }^{56}$ An indication of how smoothly the relationship operated is that $\mathrm{Mr}$ Dudgeon could not recall the exact period of the lease: 'we just paid the rent and carried on'. ${ }^{57}$

Moreover, as a farm, Humbie remained largely unchanged over this period. Although a pig house was built in $1927,{ }^{58}$ the farm remained committed to arable farming. A map of 1926 shows the division of the fields and crops with turnips, wheat, oats, rape and so much lying to lea or pasture..$^{59}$ Traditional farming methods, such as horse-ploughing, continued to be used in some farms in this area, including Humbie, even until the later $1950 \mathrm{~s} .{ }^{60}$ This type of husbandry would have been immediately recognisable to the authors of the first and new Statistical Accounts.

The 1930s did, however, bring adversity to Scottish agriculture. While the levels of unemployment were hardly comparable to the mass lay-offs in the likes of coal and shipbuilding, yet for the first time in over a century, unemployment had become an issue in the agrarian districts such as the Lothians. There was a decline in the need for labour and, at the same time, fewer opportunities for out-migration. ${ }^{61}$ It was this situation which most likely explains why Jack's Houses were allowed to become 'condemned' rather than renovated. George Dudgeon has a memory of a blacksmith living in Jack's Houses at one time. The blacksmith would visit the farm twice a week, essentially to shoe the Clydesdales on whom so much of the work of the farm depended. Other than that, he thinks that in their final years Jack's Houses would have been inhabited by Irishmen and part-timers, rather than by the more regular farm labourers. He agrees that the reason Jack's Houses were abandoned was because they became surplus to requirements, which, in turn, was due to the changing demand for labour. ${ }^{62}$

\subsection{Conclusion}

Documentary evidence has provided us with some insight into the way that many families inhabited these two small houses and used and developed their facilities over the space of a century. Study of the Valuation Rolls has provided the names and occupations of the householders. The Rolls reveal that, until the cottages were condemned in 1934 , their occupiers were agricultural workers, their occupations being more or less the same as those earlier in the 19th century. The inhabitants of Jack's Cottages were representative of the rural lowland labour force. Most came from the immediate vicinity or nearby, though there were migrants from further afield. People did move out of the area, though most seem to have remained in or near to Kirkliston. As well as geographic, there was some evidence of social mobility also. But, in the main, the occupants came from 'common stock'; their parents were of the 
Table 1 Summary of occupants based on the census and other records (* = uncertain which house was occupied by these families)

\begin{tabular}{lll}
\hline Record date & one-window & two-window \\
\hline 1841 & $*$ Sharp $\times 6$ & *Baxter $\times 9$ (to 1845+) \\
1844 & $*$ Gibson $\times 2$ & \\
1851 & $*$ Brash $\times 3$ & $*$ Gilbert $\times 4$ \\
1861 & Curron/Carr $\times 7(c$ 1859-61 max $)$ & Borthwick $\times 5(c 1859-?)$ \\
1871 & Fleming $\times 1$ & Dodds $\times 4$ (to 1873?) \\
1881 & & White $\times 6$ \\
1891 & McRiner $\times 2$ & Anthony $\times 6$ (to 1899 at least) \\
1901 & empty & empty \\
\hline
\end{tabular}

labouring class, and, mostly, their children became waged workers. For all the dramatic changes that the area experienced over that century from 1830 to 1930, Jack's Houses remained inextricably linked to the land and representative of an essential continuity.

Since the 1930s, however, there has been enormous change in the structure and operation of agriculture, and the abandonment of Jack's Houses is symptomatic of that change. To quote George Dudgeon again, 'I can't tell you the amount of change. Father had a staff of 20 in 1940, women workers, odd laddies, tractormen, cattlemen, shepherds, ploughmen. They were mainly horse-drawn vehicles in those days, and then the tractors came in during the war, and the tractors took over in the $1950 \mathrm{~s}$ and ' $60 \mathrm{~s}$, and so it went on. The staff were reduced because the tractors did more work and were down to about four tractormen and a cattleman; so there were five instead of twenty in the 1950s and '60s and then it got less and less, and there were three, there were two, and there was one, and then there were none. ${ }^{63}$ Today Humbie Farm does not employ a single worker, the last having retired in 1998, and the actual farming is done through a contractor.

The cottages which remain on the farm are inhabited by people who tend to work in Edinburgh, and who move in and out of the farm at times different from the farmer, and with little or no direct contact with him. Today, the Dudgeon family is looking to renovate some derelict buildings and turn them into holiday cottages, an indication of the ways in which the agricultural industry throughout Europe needs to diversify if it is to survive. While Humbie continues to produce some of the same crops it has always done, such as barley and wheat, as well as rape, which it started growing during the last century, others such as oats, hay, turnips and potatoes have been abandoned because they are too labour-intensive. Because of this, and the increased use of mechanisation, the society which the farm sustained has more or less completely gone. There is no longer the large number of people, both permanent and temporary, working and living on the farm, socialising together and with the farmer. As George Dudgeon expresses the change, 'in those days there were people about the steading, people tidying up, people sweeping, people feeding sheep, people feeding cattle, and now there's nobody. It's really very lonely work. ${ }^{64}$

\subsection{Summary of the findings from the census and other records, by Sue Anderson}

Table 1 presents a summary, based on the documentary evidence presented in the Appendix, of the residents of Jack's Houses between 1841 and 1891. The study of the census records highlights the transient nature of the rural population was at this time: 12 families were recorded as living at the cottages between 1841 and 1891 and it seems likely that there were others within each decade who were never recorded. 


\section{DISCUSSION \& CONCLUSIONS, Stuart Mitchell \& Sue Anderson}

The combined archaeological and historical approach to the questions raised by the study of Jack's Houses has proven useful in providing an insight into the types of people who lived in the structures which were excavated here, and this approach may be applicable to future investigations where both physical remains and documentary records co-exist. The two disciplines in tandem have provided a more holistic picture than may be gained from either method alone.

Apart from a single sherd of medieval pottery found in the evaluation, there was no evidence for activity on or near the site prior to the 19th century. It is likely that the land was in agricultural use before Jack's Houses were built.

The archaeological and historical investigations confirm that Jack's Houses were probably built between around 1838 and 1841, most likely in 1839 . The remains of the structure appear to conform with its depiction on the first and second edition OS maps $(1855,1897)$. In its initial phase it was a curvilinear building located on the north side of the road leading from Almondhill to Humbie Farm, as depicted on the early maps. An associated triangular allotment or field lay to the north. The ditch forming the eastern boundary of this field, and the draw well it contained, also appear on the first edition map and were probably contemporary with Jack's Houses. The ditch running eastwards from the structure's south-eastern corner is probably of slightly earlier or contemporary date. Field boundary walls and an entrance gateway were added, probably during Jack's Houses' period of occupation. Field drainage appears to have been introduced or, more likely, improved from the 1840s onwards with the installation of clay pipe drains (Douglas and Oglethorpe 1993). The upgrading of the Humbie Farm road, since partially built over by the A8000-M8 slip road, has slightly encroached on some of the remains including the extreme south-west edge of Jack's Houses and the midden.

The walls of the structure varied in preservation from the low sandstone footings of the southern wall to truncated foundation trenches on the other sides. These indicate that internally the eastern half of the building was $9.5 \mathrm{~m}$ long and $5 \mathrm{~m}$ wide. There was no evidence of internal partitions in the dirt floor, but presumably they existed if the cottage were to contain a separate kitchen, 'room', lobby and pantry as suggested by the records. Much of the interior of Jack's Houses had been destroyed by a modern water pipe trench, but two pits and a slot were discovered within the building and, although no stratigraphic links were present, it seems likely that these features were contemporary with the original occupation of Jack's Houses. The ash-filled slot close to the west end of the east structure could indicate the presence of a hearth close to the wall here. An annexe to the western end of Jack's Houses is shown on the first edition OS map, but no trace of the feature had survived. A brick outhouse which does not appear on any maps appears to have been a later addition.

The western end of the building was very poorly preserved, with only approximately $7 \mathrm{~m}$ of the front wall surviving. If this was the original full extent, it seems likely that this was the one-roomed/windowed dwelling referred to in the records. Possible evidence for a threshold can be discerned, but otherwise there is little evidence with which to interpret the structure.

Although both the structures had stone foundations, it is possible that they were not entirely stone-built, as some of these structures were built of turf and clay on a stone foundation. This might explain why they were in need of repair within ten years of their apparent construction date.

The draw well appears to have gone out of use during the early 20 th century, as it does not appear on the 2 nd edition map. The fill of the well contained several 20th-century artefacts, which are associable with the post-use phase of the well, during infilling or accumulation of the fill.

The midden on the south side of the Humbie Farm road opposite Jack's Houses accumulated over a short period relative to its size during the occupancy of Jack's Houses, and although it seems certain that the inhabitants of Jack's Houses would have contributed their own domestic refuse to the midden, its bulk has been shown to be of external origin, although the derivation of the material is uncertain. There is documentary evidence of street hawkers and scavengers collecting and sorting pottery and other waste in 19th-century London (Mayhew 1861) and other urban centres, and it is likely that similar practices were carried out in Edinburgh, with the removal of waste to nearby farmland. The midden may simply represent a discrete dump, although the large concentrations of ceramic material may indicate that it was imported to be used to break up clay subsoils.

The physical remains excavated at Jack's Houses have provided us with some insight into the cramped and probably unsanitary conditions in which relatively large families were expected to reside. Other than indicating that the houses had one or two windowed rooms, this kind of information is not found in the records relating to these cottages. The lack of any evidence for internal walling within the floor plan as excavated suggests 
that any division into rooms, suggested by the records for nearby cottages, was ephemeral and probably offered the occupants little in the way of privacy or storage space. The absence of any material culture beyond the most basic items such as tools and crockery directly associated with the building suggests that in any case these people probably had few possessions to clutter the meagre space they had been allotted. The houses seem to have been heated at least, as evidence of hearths was found, but a privy building appears to have been a later addition. An annexe shown to exist on map evidence was apparently so vestigial that it was not identified archaeologically. In combination, the evidence suggests houses which were cheaply built, poorly maintained and overcrowded throughout much of their existence, occupied by transient families working as agricultural labourers and living in conditions which may not have been significantly better than those of their urban peers. 


\section{ACKNOWLEDGEMENTS}

CFA wishes to thank Jim Brunt and Mike Lowrie of Roads and Transport Design, City Development, City of Edinburgh Council for their assistance during the project, and John Lawson of City of Edinburgh Council Archaeology Service, who acted as Project Manager, for his advice and assistance, and for providing information on the finds from nonmidden contexts.

The excavations were directed by Stuart Mitchell.
Illustrations were produced by Kevin Hicks. Earlier drafts of this report were commented on by Melanie Johnson, Sue Anderson and John Lawson. The project archive has been deposited with the National Monuments Record of Scotland.

While thanks are due to the above, responsibility for the final form and content of this report lies with the authors and CFA Archaeology Ltd. 


\section{NOTES}

1 NRAS, Hopetoun Estate Papers, NRAS888/38/11, Memo. 11 October 1843.

2 NRAS888/10/11, Schedules of Descriptions and Valuation of Farm Buildings on the Hopetoun Estate 1831 and 1838.

3 NRAS888/10/4, Papers relating to Humbie Cottages 1847. Mr Hope Wallace to W Murray 13 February 1846.

4 Ibid, Memorandum of agreement with contractors for building new cottages on the Humbie Farm, 13 June 1846.

5 NSA, 'Parish of Kirkliston', by Rev. Adam D Tait (1839); Mitchell 2004, p 6, identifies large sandstone blocks having been used in the construction of the cottages.

6 NRAS888/15/8, Misc. correspondence to Wm Murray, Factor, Oct-Dec 1838, William Murray to $\mathrm{Mr}$ Hope, W.S., 1 November 1838.

7 Ordnance Survey, map of the County of Linlithgow, 1855 (surveyed 1853).

8 Hutton 2002.

9 Mathias 1983.

10 The Inventories of Wealth held at Death are in the National Archives of Scotland.

11 PP 1817-18, XIV, 'Report of the Royal Commission on the Housing of the Industrial Population, Rural and Urban', p 163.

12 NAS, RHP6730, Photostat copy of plan of Humbie Farm, 1843.

13 NAS, RHP49538, Photostat copy of architectural plans, elevations, and sections of additions to Humbie Farm Cottages, 1904.

14 Campbell \& Devine 1990, p 58.

15 Ibid, p 54.

16 Royal Commission on the Housing of the Industrial Population, Rural and Urban, Evidence, Vol. II pp 1,374-5.

17 Campbell \& Devine 1990, p 60.

18 VR122/25, Valuation Roll of the County of Linlithgow, 1909-10.

19 RC, Evidence, Vol. I, p 169.

20 PP1917-18, p 170.

21 Ibid, p 165.

22 RC, Evidence, Vol. I, p 172.

23 Statistical Account, 'Parish of Kirkliston', John Muckarsie, 1792-93; NSA; Whyte 1991.

24 Devine 1994, p 60.

25 NRAS888/6/5, Papers relating to Humbie Farm, 'Articles and Conditions of Let of Humbie Farm for 19 years after Martinmas 1825'.

26 NRAS888/429, Estate Papers including, 'Memo to Humbie Farm re. new lease 25 October 1838.'

27 NRAS888/429, Estate Papers, including Professor Low's report on Humbie Farm to W Murray, factor, 28 January 1839.
28 NRAS888/38/11, Papers as to setting and relinquishing of farms, quarries, etc. 1836-47, inc. specification for five cottages at Humbie, 16 Jan 1839; NRAS888/427, Estate papers 1816 1839, including lease of Humbie Farm 1839; NRAS888/429 Estate Papers including, 'Memo to Humbie Farm re. new lease 25 October 1838.' Memoranda 1816-24

29 NRAS888/38/Bundle 11, and 888/427.

30 NAS, RHP6730, Photostat copy of plan of Humbie Farm, 1843

31 Rev. Alexander Webster conducted the first census of the population of Scotland in 1755.

32 3rd Stat Acct, 'Parish of Kirkliston' by Rev. George Irving; 'Kirkliston Since 1964' by Donald Whyte.

33 Stat Acct.

34 NSA.

35 Mitchison 2000.

36 CH3/1008/5, Kirkliston Free Church, Communion Roll 1844-55.

37 Ibid.

38 CH2/229/8 Kirkliston Parish Church, Baptismal Register.

39 PP 1844, XXII, Report from Commissioners, Poor Law Inquiry (Scotland).

40 NRAS888/6/5, Letter from Dudgeon, 3 May 1822 , accepting offer for a new lease of his farm. Tenant to pay half the portion due for schoolmaster's salary and for relief of the poor.

41 CH2/229, Kirkliston Kirk Session, Minutes; NRAS888/42/5/Bundle 8.

42 NRAS888/15/8, Account of Wages and Pensions to Yearly Servants at Hopetoun, payable at Martinmas 1847.

43 RC, Evidence, Vol. II, p. 1375.

44 NRAS888/15/8, Account of Wages and Pensions to Yearly Servants at Hopetoun, payable at Martinmas 1847.

45 See, for instance, Crowther 1993.

46 NAS, AD14/77/23, Precognition against James Anthony.

47 NAS, AD14/71/144, Precognition against Jane Baxter.

48 NAS AD14/27/21, Precognition against George Binnie and Robert Orrock.

49 NAS AD14/30/260, Precognition against Walter Omit, Peter Taylor and John Young.

50 VR122/43, 1930-31.

51 Newby 1977.

52 Howkins 1985; Snell 1985.

53 Anthony 1997; Carter 1979.

54 Interview with George Dudgeon, 10 March 2006.

55 Campbell \& Devine 1990, p 59. 
56 Interview with George Dudgeon, 10 March 2006.

57 Ibid.

58 RHP140785, 'Architectural drawing of a pig house, Humbie Farm', 1927.

59 RHP140784, Plans of Humbie Farm, c 1926.

60 Whyte 1991, p 37.

61 Anthony 1997, p 239.

62 Interview with George Dudgeon, 10 March 2006.

63 Ibid.

64 Ibid.

\subsection{Abbreviations}

NAS - National Archives of Scotland

NRAS - National Register of Archives for Scotland NSA - New Statistical Account of Scotland PP - Parliamentary Papers

RC - Royal Commission on the Housing of the Industrial Population, Rural and Urban

Stat Acct - Statistical Account of Scotland 


\section{REFERENCES}

Anthony, R 1997 Herds and Hinds: Farm Labour in Lowland Scotland, 1900-1939. Scottish Historical Review monogr ser, 3. Tuckwell Press, East Linton.

Callander, R F 1987 A Pattern of Landownership in Scotland: with particular reference to Aberdeenshire. Haughend Publications, Finzean.

Campbell, R H \& Devine, T M 1990 'The Rural Experience', in W H Fraser \& $\mathrm{R}$ J Morris (eds) People and Society in Scotland, Volume II, 1830-1914. John Donald, Edinburgh.

Carter, I 1979 Farmlife in North-East Scotland, 1840-1914: The Poor Man's Country. John Donald, Edinburgh.

Crowther, M 1993 'A Fermtoun Tragedy', Scottish Local History Journal 29, 16-20.

Devine, T M 1994 The Transformation of Rural Scotland: Social Change and the Agrarian Economy 1660-1815. Edinburgh University Press, Edinburgh.

Douglas, G \& Oglethorpe, M 1993 Brick, Tile and Fireclay Industries in Scotland. RCAHMS, Edinburgh.

Fletcher, E 1976 Antique Bottles. Blandford Press, Poole.

Howkins, A 1985 Poor Labouring Men: Rural Radicalism in Norfolk, 1870-1923. Routledge, London.

Hutton, G 2002 Scotland's Millennium Canals: the Survival and Revival of the Forth and Clyde and Union Canals. Stenlake, Catrine.

Mathias, P 1983 The First Industrial Nation: the Economic History of Britain 1700-1914. 2nd ed. Routledge, London.

Mayhew, H 1861 London Labour and the London Poor. Griffin, Bohn \& Company, London.

Mitchell, S \& Suddaby, I 2003 M9 Spur Extension \& A90 Upgrading, Edinburgh: Archaeological Evaluation. CFA Report No. 767.

Mitchell, S 2004 Jack's Houses, Kirkliston: Archaeological Excavation. CFA Report No. 859.

Mitchison, R 2000 The Old Poor Law in Scotland:

The Experience of Poverty, 1574-1845. Edinburgh

University Press, Edinburgh.

Newby, H 1977 The Deferential Worker: A Study of Farm Workers in East Anglia. Allen Lane, London.

NSA 1939 New Statistical Account of Scotland 'Parish of Kirkliston', by Rev. Adam D Tait.

Silber \& Fleming 1990 The Silber \& Fleming Glass and China Book. Wordsworth Editions, Ware.

Snell, K D M 1985 Annals of the Labouring Poor: Social Change and Agrarian England,
1660-1900. Cambridge Studies in Population, Economy and Society in Past Time, 2, Cambridge University Press, Cambridge.

Statistical Account of Scotland, 1791-1797, ed. Sir John Sinclair (Edinburgh, 1791-97), 21 vols, new edition by I Grant \& D J Withrington (Wakefield, 1975-79), 'Parish of Kirkliston', John Muckarsie, 1792-93.

Talbot, O 1974 'The evolution of glass bottles for carbonated drinks', Post-Medieval Archaeology 8 (1974)

Third Statistical Account of Scotland, The County of West Lothian, ed. Patrick Cadell (Edinburgh 1992), 'Parish of Kirkliston' by Rev. George Irving; 'Kirkliston Since 1964' by D Whyte.

Whyte, D 1991 Kirkliston: A Parish History. Kirkliston.

Wills, G 1974 English Glass Bottles for the Collector. John Bartholomew, Edinburgh.

\subsection{Unpublished sources}

\subsubsection{National map library of Scotland}

Thomson, J 1832 Atlas of Scotland

Ordnance Survey 1855 1st Edition, Linlithgowshire, Sheet VI.8

Ordnance Survey 1897 2nd Edition, Linlithgowshire, Sheet 3 (SW)

Ordnance Survey 1928 Popular Edition, Firth of Forth Sheet 68

\subsubsection{General register office, Scotland}

Census enumerator schedules for Parish of Kirkliston, County of Linlithgowshire, plus various other schedules for other parts of Scotland, 1841-1901.

Registers of Births, Marriages and Deaths, 1855 - . Old Parish Registers, Index.

\subsubsection{National register of archives Scotland}

NRAS888 Hopetoun Papers

\subsubsection{National archives of Scotland}

Inventories of Wealth held at Death. CH2/229, Kirkliston Kirk Session, Minutes. CH3/1008, Kirkliston Free Church Records. 
VR122, Valuation Rolls for Linlithgow County/West Lothian, 1855-1970.

RHP6728, Photostat copy of plan of Humbie, 1720.

RHP6730, Photostat copy of plan of Humbie Farm, 1843.

RHP6846, Photostat copy of plan of Humbie Farm, 1862.

RHP38156, Photostat copy of 'reduction' plan of those parts of the Earl of Hopetoun's estate which lie most contiguous to Hopetoun House, n.d., late 18 th century.

RHP49538, Photostat copy of architectural plans, elevations, and sections of additions to Humbie Farm Cottages, 1904.

RHP140784, Plans of Humbie Farm, $c 1926$.

RHP140785, Architectural drawing of a pig house, Humbie Farm, 1927.

\subsubsection{Parliamentary papers}

PP 1837-38, XXXIII, Third Report of the Commissioners of Religious Instruction, Scotland.
PP 1839, XXVI, Ninth Report of the Commissioners of Religious Instruction, Scotland.

PP 1844, XXII, Report from Commissioners, Poor Law Inquiry (Scotland) Part III.

PP 1844, XXIII, Report from Commissioners, Poor Law Inquiry (Scotland)) Part IV.

PP 1844, XXIV, Report from Commissioners, Poor Law Inquiry (Scotland)) Part V.

PP 1844, XXV, Report from Commissioners, Poor Law Inquiry (Scotland), Appendix to Report.

PP 1817-18, XIV, Report of the Royal Commission on the Housing of the Industrial Population, Rural and Urban.

Royal Commission on the Housing of the Industrial Population, Rural and Urban, Evidence, 4 volumes (HMSO, Edinburgh, 1921). 


\section{APPENDIX: FAMILY BIOGRAPHIES}

The difficulty associated with using census and civil registration data, as indeed with any documentation, mainly concerns its accuracy. Discrepancies in data regarding age, names, relationships etc are commonplace. The reasons for such inaccuracies can be attributed to both the recorder (registrars in the case of the civil register and enumerators, in the cases of the censuses) and the recorded (the individuals supplying the information). Registrars and enumerators often favoured particular spellings of names, eg either Agnes or Agness, Kerr or Carr, and when informants were illiterate, recorders would attempt a phonetic approximation. The transmission of inaccurate information on the part of the informant may have been inadvertent, as they may not have been in possession of the required facts. Incorrect indexing, examples of which are not infrequent, can also impede this kind of research, whilst the tracing process can also be hampered when an individual possesses a common forename and surname. This is compounded when researching such frequently occurring names before compulsory civil registration in 1855 . Despite these problems, the censuses and civil register represent excellent sources, and, with time, persistence and experience, their shortcomings may be circumvented. Keeping this in mind, the information relating to those sometime residing at Jack's Houses identified from the census returns of 1841, 1851, 1861, 1871, 1881 and 1891 is set out below.

\subsection{Baxter}

The Baxters, comprising John (37), a blacksmith, Agness or Agnes (33), George (12), John (7), Alexander (4), Allan (2), William (1), Janet (9) and Jean (6) lived at one of Jack's Houses in 1841. Since this census does not state individual relationships it is assumed that they made up a family of man, wife and seven children. This census did not specify the number of windowed rooms so it is not possible to say with any certainty which of the cottages they inhabited. Neither was place of birth specified, save indicating whether individuals were born in or outside the county of Linlithgowshire, and in this grouping, all were born outside Linlithgowshire. Therefore the Baxters could not be traced accurately further than the 1841 census due to the factors mentioned above.

The communion roll of the Free Church in Kirkliston (1844-45) recorded John Baxter and his wife at Jack's Houses. It would therefore be reasonable to assume that the family had been living at the same address for the past five years.
In 1858 John and Agnes' son Alexander, who was then living in the Canongate in Edinburgh and working as a blacksmith, married Margaret Rose, a dressmaker of the same address. Their son Allan was married in Aberdeen in 1861, where his occupation was given as 'engine smith'. His usual residence was 25 South James Street, Edinburgh. His bride was Margaret Scott, a 28 year-old spinster whose father, William Scott, was a farmer and her mother was Elizabeth Yeoman. By the 1881 census Allan and his wife had moved to 50 Anderson St, Govan, Glasgow, where he was working as an engine smith. Allan died in 1912 in Duke St, Glasgow, of chronic bronchitis.

Their son, William married in 1866 at 2 Charles Street, Aberdeen. His occupation was given as 'cloth weaver' and his bride, Ann Scorgie, was a domestic servant. They were of the same address, 11 Carmelite Street, Aberdeen. William died in Selkirk, where he had been working as a woollen weaver, almost 20 years later, on 21 March 1885.

\subsection{Gibson}

Contemporaneous with the Baxters, in 1844, a William Gibson and his wife are recorded on the communion roll of the Free Church in Kirkliston and their address is given as Jack's Houses. Unfortunately, because of the skeletal detail of this source, it was not possible to trace them further.

\subsection{Sharp}

In 1841 one of Jack's Houses was inhabited by George Sharp (45), a wright; Ellen (45); George (25), a wright; Gabriel (20), a wright; Isabella (15); and William (6). All were born in Linlithgowshire. Again, these individuals could not be traced accurately further than the 1841 census.

\subsection{Brash}

Colin Brash (40), a blacksmith who lived at Jack's Houses in 1851, was then a widower living with his two daughters, Janet (13), and Agnes (11), both at school. He died of a malignant abdominal growth in 1856 at Dalmeny. The members of the family were all born in West Lothian. His daughter Janet married Andrew Brown, an engineer, in 1859. She was then a domestic servant and the couple married according to the forms of the Free Church. Her sister Agnes, a dressmaker, married late in 
life at the age of 50 to John Notman, a widower, who was a carting contractor. Agnes died in 1910 at the Women's Hospital, Whitehouse Loan in Edinburgh. The informant for her death certificate was described as a 'trustee', indicating that Agnes left personal estate.

\subsection{Gilbert}

In 1851 Lewis Gilbert (60), farm labourer and widower of Elizabeth West, lived in one of Jack's Houses with his married daughter, Margaret (36), a housekeeper; his unmarried son, Alexander (31), who worked as a quarry labourer; and his granddaughter, Elizabeth Corstorphine (16), who was still at school. They were all born in West Lothian. The 1861 census index, given that the forename Lewis was fairly unusual, revealed that he was living with his second wife, Margaret, in Queensferry, in a dwelling with three windowed rooms, and the couple were not sharing the accommodation with anyone else. Curiously, Lewis's occupation had changed from the staple farm/agricultural labourer to that of 'spirit dealer'. A marriage between Lewis Gilbert and Margaret Potter was recorded in the Kirkliston Old Parish records for the year 1852. Further research confirmed the death of Lewis's first wife, Elizabeth West, who perished in 1848 in the parish, aged 39. The second Mrs Gilbert survived her husband by almost 30 years, dying in 1891 at East Terrace Cottage, Queensferry, aged 87. The death certificate recorded her as widow of Lewis Gilbert, labourer. She was found dead, therefore the death was not certificated by a doctor. Her grand-nephew from Dalmeny signed the certificate. Lewis died of flu and lung congestion in 1862 at Queensferry aged 72. The informant on his death certificate was a neighbour.

In 1858 Lewis's son, Alexander, now living in Glasgow and employed as a free stone cutter, married Mary Husband. They do not appear to have had any children. When he died in 1883, aged 69 and suffering from paralysis, his occupation was given as 'stationer'. Alexander's wife, Mary, died in 1899 of cardiac disease at Bonhill Poorhouse Glasgow.

Lewis had another son, William, a farmer who ran Millrigg farm at Kirknewton. William married Margaret Watt in 1853. They had two children, a boy, Lewis, and a girl, Margaret, who both died tragically of scarlet fever in quick succession aged eight and six respectively. When William died in 1894 aged 76 of an embolism and gangrene of the leg, he was retired and left a personal estate of $£ 1,48912 \mathrm{~s} 6 \mathrm{~d}$. His sister Margaret, widow of Thomas Corstorphine, died the same year at the same address leaving a personal estate of $£ 2,16512 \mathrm{~s} 10 \mathrm{~d}$, a large amount of this sum having been left to her by her brother William.

Lewis Gilbert's granddaughter, Elizabeth Corstorphine, never married. When she died at Portobello in 1909 suffering from general paralysis she was 74 years old and an annuitant.

\subsection{Curron or Curran}

In 1861 Patrick Curron (35), an agricultural labourer, was residing in the one-windowed-room dwelling of Jack's Houses, which he shared with his wife Bridget (38, maiden name, Kerr or Carr), also an agricultural labourer, his daughter Margaret (3) and son Samuel (2), his niece Elizabeth Kerr or Carr (12), his mother-in-law Mary Kerr or Carr (70), and brother-in-law, Samuel Kerr or Carr (24), an agricultural labourer. Patrick, his wife, mother-inlaw and brother-in-law all originated from Ireland whilst his niece was born in Aberdeen and his son and daughter in Kirkliston. His son Samuel died of scarlet fever in 1864 aged five. His mother-in-law died two years later at Humbie Quarry.

In the 1871 census, Patrick, still working as a farm labourer (his age now given as 42 ) was residing at Humbie Quarry in a one-windowed-room house with his wife Bridget (age given as 43) and niece, Elizabeth (age given as 20), working as a farm servant, as was his daughter Margaret, now aged 13. Also part of the household was his son John (10 years old); his niece Joan (6 years old), and infant nephew Robert. The latter three were all born in Linlithgow.

It is interesting to note the stark contrast with the next entry in the census which was the Dudgeon family, the tenant farmers of Humbie. The Dudgeon household comprised four adults: Robert and George Dudgeon, unmarried brothers aged 62 and 72 respectively, together with two servants, Elizabeth Andrew (45) the cook, and Elizabeth Buchanan (28) the housemaid, and they occupied a 14-windowedroom house. The juxtaposition with the Currans having four adults and three children occupying a one-windowed room living nearby demonstrates the massive inequities in housing of this time.

In 1881 Patrick Curran was working as a cattle feeder and living at Humbie quarry with his wife Bridget and son John and nephew Robert Curran, both agricultural labourers aged 19 and 14 respectively. Patrick died in 1891 at Broxburn aged 68 and his occupation was given as 'labourer'. The cause of death on the certificate was 'old age'. His wife, Bridget Carr, died three years later aged 76 at Broxburn. Her death was attributed to 'age and debility'. Patrick's daughter Margaret, who married Thomas Tighe, a general labourer, died in 1925 aged 68 at the Royal Infirmary of Edinburgh (her usual residence was in Broxburn).

\subsection{Borthwick}

In 1861 James Borthwick (30), an agricultural labourer, was living in the house with two windowed rooms at Jack's Houses together with his wife Ann 
(29), also an agricultural labourer, his daughters Janet (4), Jane (2) and his niece Jane Cowper (1), who was listed as a boarder with the family. James and his wife Ann were born in Kirkliston. Their daughters were both born at Humbie and his niece at Corstorphine. By the time of the 1881 census James was employed as a cellarman and he and Ann were living in Kirkliston with their three sons, Ramsay (15), a railway porter, James and David aged 12 and 6 respectively and his father Ramsay Borthwick, a retired farm servant aged 73. All were born in West Lothian. Four years later James died at the same address, aged 56, of a strangulated hernia and peritonitis. His wife died five years later at the same address of congestion of the lungs and general paralysis. She left a personal estate of $£ 4712 \mathrm{~s} 6 \mathrm{~d}$.

In 1884 his daughter Janet married Peter Swan, an engine keeper, and they settled in the Linlithgow/ Philipstoun district. They had at least five children. A year later his daughter Jane married John Rodger, a saddler, and had at least eight children.

\subsection{Dodds}

Anthony Dodds and his family resided in the house with two windowed rooms at Jack's Houses in 1871. He was then aged 27 and worked as a coachman and gardener and was born in Ancrum, Roxburghshire. His wife, Margaret (33), came from Eckford in the same county and his son George (4) was born in Ayton, Berwickshire, while his daughter Agnes (3) was born in Ladhope, Roxburghshire. The previous census (1861) found 16 year-old Anthony in the Ancrum district of Roxburgh, where he was working as a ploughman for a farmer called Thomas Stoddart who owned 700 acres. He was living at Woodhead farmhouse with the farmer's family and several other servants. Meanwhile, Anthony's family were housed nearby at Woodhead cottages on 'Blackhill' farm, where his father was employed as a farm steward, sharing the one-windowedroom accommodation with his wife and Anthony's younger siblings, all boys, aged 11, 8, 5, 3 and 10 months. At the following census (1881), the family were situated in Kirkcaldy, where Anthony was employed as a jobbing gardener. He then had three more children, Anthony (8), William (6) and Jane Ellen (4), all attending school. The boys were born in Dumbarton and the daughter at Twynholm, Kirkcudbrightshire.

The next census found the family living in accommodation with four windowed rooms in Kirkcaldy. Anthony, then 48 years old, was working as a coachman, his wife Margaret was 53 years old. Their son George (24) was employed as a linen calenderer, their son Anthony (18) as a painter, William (17) a grocer's assistant while daughter Agnes (23) was an unemployed domestic servant. Daughter Jane Ellen was employed as a general servant in a large house in Kirkcaldy. His wife, whose maiden name was Margaret Smail, died in 1898 in Leith aged 62 of chronic phthisis pulmonalis (TB). In the 1901 census Anthony was a gas works labourer living in Leith with his daughter Agnes, now head of the household, who was still unmarried and a confectioner working on her own account, as well as his niece, Lilly Dodds, aged 9. It was one-windowedroom accommodation.

Anthony Dodds died from cerebral thrombosis in 1919 at Craiglockhart Poorhouse aged 75.

\subsection{Fleming}

In 1871 Agnes Fleming, a young widow aged 27, born in Aberdeen and employed as an out-worker, appeared to inhabit the one-windowed-room house by herself. It was not possible to trace her further.

\subsection{White}

The 1871 census recorded the White family living in a one-windowed house in Penicuik: their details were as follows: head of household Robert White, a shepherd, aged 38; Janet, his wife, aged 35; daughters Margaret, Caroline and Janet aged 12, 10 and 1 respectively; and sons James, Robert and George aged 8, 6 and 3 respectively. Their youngest child, Janet, did not survive to the next census, dying of croup when she was 4 years old, at Dalmeny. In 1881 Robert White (47), a shepherd born in West Calder, Midlothian was living in the house with two windowed rooms at Jack's Houses. With him were his wife Janet (44) born at Walston, Lanarkshire and employed as a servant, two unmarried daughters, Margaret (21) and Caroline (20), both servants and born respectively in Stow and Temple in Midlothian. Two sons also stayed there; Robert (15), an agricultural labourer, and George (13), both of whom were born in Penicuik, Midlothian. In the 1891 census, though alive at the time, Robert White was not recorded living with his family (perhaps he was outdoors tending to sheep at that time). In any case, his wife Janet, then 55 years old and working as an agricultural labourer, was recorded as head of household. She was living in a house with two windowed rooms near Currie, Midlothian, with her unmarried son James (27), an agricultural labourer born in Eddleston, Peeblesshire (who had not been recorded as living with the family in the 1881 census but appears in the household in the 1871 census), and her unmarried daughter Caroline, a domestic servant.

Robert White was found dead in his house at Balerno in 1893 aged 59. His occupation was recorded as shepherd. In the 1901 census his widow Janet was described as an annuitant living with her unmarried daughter Caroline, an outdoor worker. They were living in three-windowed-room accommodation near Currie. Janet died in 1909 of heart disease at Easter Currie. Her daughter Caroline 
died of heart failure in 1926, her usual residence was Humbie at Kirknewton and her occupation given as 'farm worker'.

\subsection{Anthony}

Old parish records reveal that James Anthony's parents were married on 28 August 1839 at Kirknewton, East Calder. Records of the birth of four children born before civil registration were found: William, born in 1840; Janet, born in 1842; another William, born in 1844; and a John born in 1850 . Since two children bear the same name it is assumed the first-named child in each case died (before civil registration, baptisms and marriages were often recorded, whereas deaths often went unrecorded). Also, it is common for the ages of individuals to be approximate rather than strictly accurate.

The 1861 census records James Anthony as a 3 year-old living in Colinton Farm Cottages, Midlothian with his father, William Anthony, a 45 year-old agricultural labourer; his mother Grace (41 years); sisters Janet (a 14 year-old farm servant) and Agnes, a schoolgirl aged 9; and brothers John, James and Richard, aged 6, 3 and 5 months respectively. Also residing with them in their accommodation of two windowed rooms, was a lodger, Elizabeth Elder, a widow aged 47 who was born at Fort George.

The next census (1871) found James Anthony, then aged 13, living with his parents William Anthony (56), an agricultural labourer and Grace (50) born at Bathgate and Ratho respectively, together with siblings Agnes, John and Richard, 19, 16 and 10 years old respectively, and all born at Colinton. By the time of the 1881 census James was working as a blacksmith and lodging with a family of eight (the Skeds) in Ratho.

James's father, William, died in 1893 aged 79 years at Colinton of cardiac disease and 'softening of the brain'; his occupation was given as a ploughman

In 1891 James Anthony (32), blacksmith born at Colinton, Midlothian occupied the house with two windowed rooms at Jack's Houses with his wife, Georgina (31) born in Lasswade, Midlothian, and sons William (7), George (6), James (4) and Alexander (1), all born at Ratho. In 1901 James occupied Humbie farm cottage, which had two windowed rooms. With him were his wife, sons William (17) apprentice grocer, George (16) Post Office messenger and James (14) apprentice wood turner, as well as Bessie (8), John (5) and Charles (2). The latter three children were all born at Jack's Houses. The youngest child, Bessie Anthony, a dressmaker, married Peter Fulton, a cashier in 1917 in Edinburgh and appeared to have had two children; Georgina, born in 1918 and John, born in 1920. Both children were born in Edinburgh. Bessie died in Edinburgh in 1962 aged 70, as a result of coronary thrombosis.

In 1927 James Anthony's wife Georgina died in Edinburgh of arterial sclerosis and cerebral haemorrhage. Ten years later James himself died aged
79 suffering from chronic nephritis and anasarca at the same address.

\subsection{MCRiner}

In the 1851 census, Peter, aged 29, was working as an agricultural labourer and resided at Ormiston Castle, Kirknewton, East Calder with his wife, Mary, 30, and daughter Catherine, aged 5, and two younger daughters, Agnes and Isabella.

The 1871 census found Peter McRiner and his family at Ochiltree Castle in a house with two windowed rooms. He was then recorded as being a farm servant, aged 48, his wife Mary, an agricultural labourer, aged 49. His unmarried daughter, Catherine, aged 24 and her son George, aged 12 months were also living with them. This illegitimate child became a farm grieve and died of influenza and myocarditis aged 73 in 1945 at Overtoun farm cottage, Kirkliston. George's children could still be traced in the West Lothian area until recently. Also, whilst interviewing the farmer George Dudgeon of Humbie farm, the McRiner name and its association with the farm was familiar to him.

Peter McRiner could not be traced in either the 1861 or 1881 censuses. This could mean that the family were out of the country. However, a search for the family in the British census of 1881 yielded nothing. The more likely explanation of the mysterious disappearance of the McRiners in these two censuses is either evasion on the part of the McRiners or enumerator error.

In 1891 the house with one windowed room at Jack's Houses was inhabited by Peter McRiner (64), a roadsman, and his wife Mary (62). Peter was born at Ratho and Mary, at West Calder. Peter and Mary (maiden name Nicol) had married in Linlithgow in 1842. By 1855 they had had their sixth child, James. His siblings were two male and three female, one of whom had died. In 1870 one of his daughters, Agnes (20) married a ploughman, Andrew Morton (26) in Linlithgow, and by 1881 they were living near Bathgate, where Andrew worked as a farm servant, and had five children. In 1891 the Mortons had moved to Edinburgh, and with his brother, James, then living with them, Andrew Morton had set up a dairy business. There were four more children, and elder children were most likely employed in the business as they had occupations such as dairymaid and van man, whilst one offspring was a dressmaker. In 1901 the family was at the same address in Edinburgh carrying out the same business. Although a few of the older children had left home most, except for the youngest two (who were attending school), were employed in their father and uncle's business.

Agnes Morton (maiden name McRiner), died in 1911 at the old hospital at Restalrig, Edinburgh of pelvic cancer aged 61

Peter McRiner died aged 78 in 1896 at Kirkliston. His occupation was given as 'roadsman' and cause 
of death was bronchitis. Though in his latter years he was mainly employed as a roadsman, he had also worked as a ploughman and an agricultural labourer. Mary McRiner survived her husband by four years.
After being recorded in the 1901 census as living on the parish relief with her sister at Overtoun Farm, Kirkliston, she died later that year, aged 74, of heart failure. 